\title{
The Environmental and Public Health Benefits of Achieving High Penetrations of Solar Energy in the United States
}

\author{
Ryan Wiser ${ }^{1 *}$, Dev Millstein ${ }^{1}$, Trieu Mai ${ }^{2}$, Jordan Macknick ${ }^{2}$, Alberta Carpenter ${ }^{2}$, Stuart Cohen ${ }^{2}$, \\ Wesley Cole ${ }^{2}$, Bethany Frew ${ }^{2}$, Garvin Heath ${ }^{2}$ \\ ${ }^{1}$ Lawrence Berkeley National Laboratory \\ ${ }^{2}$ National Renewable Energy Laboratory \\ * Corresponding author
}

\begin{abstract}
We estimate the environmental and public health benefits that may be realized if solar energy cost reductions continue until solar power is competitive across the U.S. without subsidies. Specifically, we model, from 2015-2050, solar power-induced reductions to greenhouse gas (GHG) emissions, air pollutant emissions, and water usage. To find the incremental benefits of new solar deployment, we compare the difference between two scenarios, one where solar costs have fallen such that solar supplies $14 \%$ of the nation's electricity by 2030 and $27 \%$ by 2050 , and a baseline scenario in which no solar is added after 2014. We monetize benefits, where credible methods exist to do so. We find that under these scenarios, solar power reduces GHG and air pollutants by $\sim 10 \%$, from 2015-2050, providing a discounted present value of \$56-\$789 billion (central value of $\sim \$ 250$ billion, equivalent to $\sim 2 \phi / \mathrm{kWh}$-solar) in climate benefits and $\$ 77-\$ 298$ billion (central value of $\$ 167$ billion, or $\sim 1.4 \phi / \mathrm{kWh}$-solar) in air quality and public health benefits. The ranges reflect uncertainty within the literature about the marginal impact of emissions of GHG and air pollutants. Solar power is also found to reduce water withdrawals and consumption by $4 \%$ and $9 \%$, respectively, including in many drought-prone states.
\end{abstract}

\section{Keywords}

Solar energy; greenhouse-gases; air pollution; public health; co-benefits; water use

\section{Introduction}

The contribution of solar energy to global (EPIA 2014) and U.S. (GTM/SEIA 2015) electricity supply is modest but growing rapidly - a consequence of steep reductions in the cost of solar energy (Barbose et al. 2015; Bolinger and Seel 2015) and, in the United States, a wide array of policy measures at the state and federal levels (Sarzynski et al. 2012; Shrimali and Jenner 2013). At the federal level, in addition to programs that provide direct financial assistance to solar power projects, such as the investment tax credit, the United States has developed a targeted research program (the SunShot Initiative ${ }^{1}$ ) designed to bring new solar technologies to market and to reduce the costs of deploying existing technologies. A primary goal of the SunShot Initiative is to reduce the total installed cost of utility solar photovoltaics to $1 \$ / \mathrm{W}_{\mathrm{dc}}$ by 2020 , with concomitant reductions in the cost of other solar applications and technologies,

\footnotetext{
${ }^{1}$ For more about the SunShot Initiative, see energy.gov/eere/sunshot/sunshot-initiative.
} 
strengthening the role of solar as a low-cost energy source and motivating higher levels of solar electricity supply in the near, medium, and longer term.

Achieving these cost reductions would have profound implications for the solar industry, the electricity sector as a whole, end-use electricity consumers, and the environment. Substantial progress has already been made in meeting the SunShot cost goal, though additional effort is required to ensure success by 2020 (Woodhouse et al. 2016). The SunShot Vision Study (DOE 2012) used an electric sector capacity-expansion model (the National Renewable Energy Laboratory's Regional Energy Deployment System, or NREL's ReEDS) to evaluate the implications of achieving the SunShot cost targets for the United States, finding overall solar electricity penetrations of $14 \%$ of annual U.S. electricity demand by 2030 and $27 \%$ by 2050 . While that study provided a detailed estimate of where and when solar would be deployed over time, it did not comprehensively quantify the potential environmental and health benefits associated with achieving these levels of solar penetration.

We fill this gap by assessing an important subset of the potential environmental and health benefits of achieving the solar penetrations envisioned by DOE (2012). The environmental and public health benefits of solar primarily derive from avoiding combustion-based electricity generation. The environmental impacts of electricity generation are described by NRC (2010). Depending on the fuel and technology type, combustion-based electricity generation emits greenhouse gases, pollutants such as particulate matter $\left(\mathrm{PM}_{2.5}\right)$ and $\mathrm{PM}_{2.5}$ precursor gases such as sulfur and nitrogen oxides. Nitrogen oxides can also contribute to ozone air pollution. Combustion-based generation units also typically withdraw and consume water for cooling purposes. Though combustion-based electricity imposes myriad other environmental burdens, greenhouse gases, criteria air pollution, and water use are regularly cited as among the most pressing concerns (NRC 2010), and among the most important environmental impacts that might be avoided with solar energy (Sinha et al. 2013).

Given the observations above, in this analysis we cover greenhouse-gas (GHG) emissions reductions, air-pollution health and environmental impacts, and water-use reductions. We use a scenario-analysis approach where the 14\%-by-2030 and 27\%-by-2050 "SunShot Vision" scenario is compared with a "No New Solar (NNS) baseline" scenario in which no new solar is deployed after 2014. This framework allows us to assess the potential benefits of all incremental solar deployment. We again employ NREL's ReEDS to conduct our analysis, updating the analysis conducted in DOE (2012). We take the modeled output from ReEDS and then apply additional tools - as necessary - to assess potential benefits in physical and, where feasible, monetary terms. Various aspects of this work build on or complement approaches used in the recent Wind Vision report (DOE 2015) and those used by U.S. regulatory agencies (GAO 2014; EPA 2015c) and academic researchers (NRC 2010; Arent et al. 2014; Buonocore et al. 2016; Callaway et al. 2015; Cullen 2013; Graff Zivin et al. 2014; Driscoll et al. 2015; Fann et al. 2012; Johnson et al. 2013; Kaffine et al. 2013; McCubbin and Sovacool 2013; Novan 2014; SilerEvans et al. 2013; Shindell 2015).

The focus of this analysis is narrow. We do not assess the full array of possible environmental and health benefits, instead choosing to emphasize what are - as described above — three of the most notable benefits (Sinha et al. 2013). Moreover, decision-makers will wish to compare these potential benefits with, among other things, the potential costs and risks introduced by adding 
solar to the electric system as well as the potential negative impacts of solar on local ecosystems and communities. Though we do not address electric-system costs or impacts in this analysis given its restricted scope, DOE (2012) provides an initial assessment of them. Other papers in the DOE's On the Path to SunShot Study series also help inform such comparisons: Denholm et al. (2016) and Palmintier et al. (2016) assess electric-system integration challenges, for example, while Chung et al. (2016) highlight the potential impacts of the solar industry on domestic manufacturing and jobs. Finally, while our results are dependent on the specific modeled scenarios, we describe how our results are sensitive to various assumptions across our analysis. With these caveats, our methods, results, and discussion provide generalizable insights into the potential for increased solar power to provide environmental and public health benefits.

Section 2 provides an overview of the methods used, including background information about the ReEDS model, key assumptions that drive the scenario analysis, and a description of the specific methods used to estimate emissions and water usage impacts. Section 3 presents a summary of the scenario results as they relate to solar deployment and the GHG, air quality, and water usage impacts and is followed by brief concluding remarks in Section 4 that highlight both the key implications and limitations of the analysis in informing decisions.

\section{Methods}

\subsection{Electric-System Modeling and ReEDS}

As in the SunShot Vision Study (DOE 2012), the electric-sector analysis for the present assessment relies primarily on NREL's ReEDS model. We use ReEDS model version 2015.2, which is most closely linked to the versions used in the Wind Vision study (DOE 2015) and in the NREL 2015 Standard Scenarios Annual Report (Sullivan et al. 2015). The Solar Deployment System (SolarDS) rooftop photovoltaic (PV) consumer-adoption model (Denholm et al. 2009) was used to generate the distributed generation PV (DGPV) trajectory in the SunShot Vision Study (DOE 2012), and is applied for the present analysis.

ReEDS is an electric sector capacity-expansion model for the continental United States that relies on an optimization algorithm to estimate the type and location of new fossil, nuclear, renewable, and storage capacity and generation; transmission-expansion requirements; and fuel needed to satisfy regional demand requirements and maintain resource adequacy, all at least cost. ReEDS is a sequential linear program that models two-year solve increments from 2010 to 2050 and finds the least cost solution based on 20-year net present value costs for new capital infrastructure, operating costs, and fuel costs used to operate the continental U.S. electric system. ReEDS represents technological, physical, and policy constraints in its scenario development. It considers the characteristics of renewable energy technologies in estimating future electricsystem investments by using high spatial resolution and statistical methods that account for the impacts of renewable variability, uncertainty, and resource distribution and quality. The constraints in the model help to ensure resource adequacy for all amounts of renewable shares in the system. ReEDS endogenously estimates transmission-expansion needs, potential increases in ancillary-service requirements due to renewable energy forecast errors, renewable curtailments, and the changing capacity credit of renewable energy technologies, and incorporates these estimates in its investment decisions.

ReEDS has been used in multiple recent analyses, including the original SunShot Vision Study (DOE 2012) and SunShot sensitivity analysis (Eurek et al. 2013), other renewable technology 
visions (DOE 2008; DOE 2015; Mai et al. 2014; NREL 2012), solar technology-specific assessments (Denholm et al. 2012; Sigrin et al. 2014; Cole et al. 2015), and policy analysis (Mai et al. 2016; Bird et al. 2011; Lantz et al. 2014; Logan et al. 2013; Mignone et al. 2012; Sullivan et al. 2014). The model documentation can be found in Short et al. (2011) with more recent model improvements described in Sullivan et al. (2015).

\subsection{Key Data Assumptions}

Our scenario modeling builds on the SunShot Vision Study (DOE 2012) by developing two scenarios of continental U.S. electricity systems out to 2050: (1) a SunShot Vision scenario that mirrors the solar deployment trends of the SunShot scenario in DOE (2012), and (2) a No-NewSolar (NNS) baseline scenario as the relevant point of comparison. The NNS baseline scenario is purely a comparison case, enabling us to estimate the full potential environmental and health benefits of all new (2015-2050) solar deployed in the SunShot Vision scenario. This scenario construct differs from that from the SunShot Vision Study in that in the original study, ReEDS was used to project the amount of solar deployment given successful cost reductions for solar technologies. In contrast, here we assess the impacts of solar under scenarios with penetration levels governed by the solar results from the original study and compared to a NNS baseline.

We rely on input data assumptions recently developed and used for the NREL Standard Scenarios Annual Report (Sullivan et al. 2015) and the Wind Vision study (DOE 2015). These include cost and performance assumptions for non-solar renewable technologies. We model wind technologies using the "central" wind cost case from the Wind Vision study (DOE 2015), which projects wind levelized cost of energy reductions from 2014 levels of $16 \%$ by 2030, and $22 \%$ by 2050. For non-renewable technology assumptions - including fossil and nuclear capital costs, operations and maintenance costs, and heat rates - we rely on data from the Energy Information Administration's Annual Energy Outlook (AEO) 2015 Reference scenario (EIA 2015a). We also use AEO 2015 Reference scenario demand growth results and fuel-natural gas, coal, and uranium - costs. Average coal prices are assumed to grow from about \$2.30/MMBtu (\$2.20/GJ) in 2016 to about $\$ 3.00 / \mathrm{MMBtu}(\$ 2.80 / \mathrm{GJ})$ in 2050. Natural gas prices are assumed to grow from about $\$ 4.50 / \mathrm{MMBtu}(\$ 4.30 / \mathrm{GJ})$ to $\$ 9.20 / \mathrm{MMBtu}(\$ 8.70 / \mathrm{GJ})$ over the same time period. ${ }^{2} \operatorname{ReEDS}$ includes regional supply curves (informed by the AEO 2015 Reference scenario) to treat the elastic interactions between electric-sector natural gas demand and price. Solar technology costs are closely aligned with those used in the SunShot Vision Study; new concentrated solar power (CSP) is presumed to include thermal energy storage. Because the modeled scenarios have prescribed solar-penetration levels, following the original SunShot Vision report (DOE 2012), different solar technology assumptions will not yield significant differences in deployment.

The modeling includes existing (as of 2015) policies and regulations only. State renewables portfolio standards, including those with solar-specific targets, and California's carbon cap are modeled in ReEDS. Although we recognize the ongoing uncertainties associated with federal air regulations, we include estimated retirement, retrofit, and dispatch impacts of the Cross State Air Pollution Rule (CSAPR) and the Mercury Air Toxics Standard (MATS) in our scenario modeling (see section 2.3.2 for additional details). Importantly, we do not explicitly model the U.S. Environmental Protection Agency (EPA) Clean Power Plan (CPP) regulation on power

\footnotetext{
${ }^{2}$ Fuel prices are presented in real 2015 U.S. dollars and reflect the weighted average based on fossil fuel usage in ReEDS and natural gas price-demand elasticities endogenously modeled.
} 
plant emissions; however, we do estimate the possible benefits of solar in meeting CPP compliance obligations as discussed later. The model does not include the end-of-2015 investment and production tax credit extensions, although this omission will not meaningfully impact the results of our analysis given the scenario design described earlier. See Mai et al. (2016) for a discussion of the impact of the tax credit extensions on renewable energy deployment.

\subsection{GHG emissions, air pollutant emissions, and water usage}

For each scenario we calculate power plant operational water usage and power plant operational emissions of $\mathrm{CO}_{2}, \mathrm{SO}_{2}, \mathrm{NO}_{\mathrm{x}}$, and primary $\mathrm{PM}_{2.5}$. For GHG emissions we also calculate life-cycle emissions. In all cases we compare the difference in the SunShot Vision scenario relative to the NNS baseline scenario and we compare across the full analysis timeframe: 2015-2050.

\subsubsection{GHG emissions}

In addition to operational $\mathrm{CO}_{2}$ emissions, calculated within ReEDS, life-cycle GHG analysis includes emissions from (1) ongoing fuel-cycle emissions from the production and transport of fuels and from other aspects of power plant operations; (2) construction-related emissions; and (3) emissions from end-of-life decommissioning. We developed median life-cycle, noncombustion GHG emission values for each generation technology and for the fuel cycle, construction, and decommissioning phases based on NREL's LCA Harmonization project ${ }^{3}$ literature. To estimate non-combustion GHG emissions from the fuel cycle, we use the electricity-production estimates (in MWh) provided by ReEDS for all generation technologies and apply the median, literature-derived estimates of technology-specific, non-combustion fuelcycle GHG emissions. We assume that biomass GHG combustion emissions are entirely offset by carbon absorption to produce the biomass feedstocks. To estimate GHG emissions from construction, we use the capacity estimates (in MW) provided by ReEDS over the 2015 to 2050 timeframe and apply the median, literature-derived estimates of technology-specific, construction-related GHG emissions. Finally, to estimate GHG emissions from decommissioning ${ }_{2}$ we use decommissioning capacity estimates (in MW) provided by ReEDS over the 2015 to 2050 timeframe and apply the median, literature-derived estimates of technology-specific, decommissioning-related GHG emissions. This approach was used in DOE (2015), where the methods are described in greater detail.

\subsubsection{Air pollutant emissions}

Combustion-related power-sector emissions of $\mathrm{SO}_{2}$, and $\mathrm{NO}_{\mathrm{x}}$ are estimated within ReEDS.

Within ReEDS, generation is multiplied by $\mathrm{SO}_{2}$ and $\mathrm{NO}_{x}$ emission rates across each power plant type and location to estimate total $\mathrm{SO}_{2}$ and $\mathrm{NO}_{\mathrm{x}}$ emissions. ReEDS emission rates were developed based on recent measurements of power plant emissions (Ventyx 2013) and $\mathrm{SO}_{2}$ emission rates were updated to meet MATS' $\mathrm{SO}_{2}$ emission 'alternate' limits starting in 2016 (EPA 2011). Combustion-related $\mathrm{PM}_{2.5}$ emission estimates are developed for both scenarios as the product of ReEDS generation outputs (MWh, by generation type and vintage) and average emission rates (grams/MWh, by generation type). Average $\mathrm{PM}_{2.5}$ emissions rates (reported by Argonne National Laboratory: Cai et al. 2012; Cai et al. 2013) are differentiated by generation type (coal, gas, or oil) and U.S. state. Additionally, $\mathrm{PM}_{2.5}$ emission factors are adjusted over time

\footnotetext{
${ }^{3}$ see http://www.nrel.gov/harmonization
} 
to comply with scheduled $\mathrm{PM}_{2.5}$ MATS limits for existing plants (for more details see Appendix L of the Wind Vision report, DOE 2015).

\subsubsection{Water usage}

Power sector water usage comes in two forms. Withdrawal is defined as water removed from and then returned to a source. Consumption is defined as water that is removed but not returned to its source. Withdrawals include cooling water returned to its source at a higher temperature and consumption includes water evaporated for cooling. Power-sector water withdrawal and consumption was estimated within ReEDS. ReEDS includes representations of cost, performance, and water-use characteristics by generation type and cooling-system technology, and new power plant construction is limited by water availability (Macknick et al. 2015). ReEDS includes four types of thermal power plant cooling systems: once-through, pond, recirculating, and dry cooling. Cooling systems for the existing fleet are assigned to ReEDS balancing-area generating capacity based on an analysis of individual electric-generating units aggregated at the ReEDS balancing-authority level, as described elsewhere (Averyt et al. 2013; UCS 2012). Following Macknick et al. (2012) and Tidwell et al. (2013), new power plants modeled in ReEDS do not have the option of installing once-through cooling technologies. The basic approach used here has been applied in multiple studies evaluating the national and regional water impacts of the U.S. electricity sector (Clemmer et al. 2013; DOE 2015; Macknick et al. 2012; Macknick et al. 2015; Rogers et al. 2013).

We focus exclusively on operational water-use requirements because thermoelectric water withdrawals and consumption during plant operations are orders of magnitude greater than the demands from other life-cycle stages (Meldrum et al. 2013). Thermal power plants using oncethrough cooling withdraw far more water for every megawatt-hour of electricity generated than do plants using recirculating cooling systems. For water consumption, however, once-through cooling has lower demands than recirculating systems. Dry cooling can be used to reduce both water withdrawal and consumption for thermal plants but at a cost and efficiency penalty (EPA 2009). Non-thermal renewable energy technologies, such as PV and wind, do not require water for cooling and thus have very low operational water-use intensities. Some PV facilities use a relatively small amount of water for washing panels, but not every PV facility washes panels. CSP facilities can use dry-cooling systems to minimize water use; wet and hybrid cooling impose greater water demands.

Related to water usage, a simplifying assumption included in the SunShot Vision scenario is that all new CSP capacity is modeled with cost and performance characteristics consistent with dry cooling. To test the impact of this assumption we performed a sensitivity analysis to analyze variations in water use resulting from different CSP cooling systems (see Section 3.4). In this sensitivity analysis, new CSP capacity is built assuming an equal distribution (one third each) of dry cooling, wet cooling using a recirculating cooling system, and hybrid wet-dry-cooling. Wetcooled CSP systems can withdraw and consume water at 10 times the rate of dry cooling, with hybrid-cooled CSP systems falling in between (Turchi et al. 2010; Macknick et al. 2012). Wetand hybrid-cooled CSP systems generally have lower costs and higher efficiencies than drycooled CSP systems; these benefits and tradeoffs are not included in the sensitivity analysis, because we focus exclusively on environmental outcomes. 


\subsection{Valuation of emission reductions and water savings 2.4.1 GHG emissions valuation}

We estimate the monetary benefits of reduced climate-change damages from GHG reductions using Social Cost of Carbon (SCC) estimates. The SCC provides an estimate of climate change induced monetary damages to agricultural productivity, human health, property, ecosystem services, and other systems. U.S. government regulatory bodies use the U.S. Interagency Working Group (IWG) SCC estimates (IWG 2010; IWG 2015) when formulating policy (GAO 2014; Kopp and Mignone 2012). The IWG SCC estimates represent global future damages from GHG emitted in a particular year, with the future damages calculated in present value terms using selected discount rates. As recommended by the IWG, we use four different IWG SCC trajectories, spanning an estimated range of climate change impact intensity as well as plausibly appropriate discount rates to find the monetary value of reduced GHG emissions over time.

As an alternative to valuing GHG reductions based on the SCC, we also value those reductions based on the possible cost of complying with legal requirements to reduce GHG emissions. The EPA may limit GHG emissions from existing and new power plants through the Clean Power Plan (EPA 2015a; EPA 2015b; Luckow et al. 2015). When binding cap-and-trade programs are used to limit GHG emissions, the climate-change benefits of solar energy might best be valued based on the cost of complying with legal requirements to reduce carbon emissions (Barbose et al. 2008; Cullen 2013; Siler-Evans et al. 2013). In this case, the GHG co-benefits of solar energy come in the form of helping to meet the carbon-reduction target and thereby offsetting some of the "marginal" costs of complying with the policy.

We value the GHG reductions based on two sets of compliance cost estimates. First, we use EPA estimates of the average national cost of complying with the CPP under both mass-based and rate-base application (EPA 2015a). While EPA has also estimated state-level marginal carbonabatement costs, we prefer to use national average estimates because of the uncertainty introduced at the state-level due to the flexibility allowed in a state achieving the CPP. Also, average cost estimates may be more appropriate than marginal estimates as the carbon reductions envisioned in the SunShot Vision scenario represent a sizable contribution to CPP compliance. Those estimates are provided by EPA for 2020, 2025, and 2030: we interpolate between these years to estimate costs in intervening periods. We assume the 2030 compliance cost estimates remain constant through 2050. Second, we use Synapse estimates of carbon costs under "low," "medium," and "high" trajectories (Luckow et al. 2015). Synapse considers the possibility of more-stringent long-term carbon-reduction goals than envisioned by the CPP and so estimates higher costs than those from EPA (2015a). Finally, note that we apply the IWG SCC estimates to the estimated life-cycle GHG emissions savings (in $\mathrm{CO}_{2} \mathrm{e}$ ), whereas we apply compliance cost estimates only to combustion-related power-sector emissions (only $\mathrm{CO}_{2}$ ) because EPA CPP regulations apply principally to the power sector. Figure 1 summarizes both sets of resulting carbon costs that we use to value the benefits of solar energy: those based on SCC and those based on regulatory compliance cost savings..

\section{FIGURE 1 HERE}

\subsection{2 $\mathrm{SO}_{2}, \mathrm{NO}_{\mathrm{x}}$ and primary $\mathrm{PM}_{2.5}$ emissions valuation}

We calculate a range of health and environmental benefits (including reduced morbidity and mortality outcomes and total monetary value) from emissions changes based on two different 
peer-reviewed approaches. Both approaches include representation of pollutant transport and chemical transformation in order to assess population exposure and response. We use (a) The Air Pollution Emission Experiments and Policy analysis model (AP2, formerly APEEP; described in Muller et al. 2011), and (b) EPA's marginal benefit methodology developed for the CPP (EPA 2015a; EPA 2015c). To incorporate differences across epidemiological studies, the EPA CPP approach includes two estimates of health impacts. The first approach, hereafter called "EPA Low," is based on work by Krewski et al. (2009) and Bell et al. (2004). The second approach, hereafter called "EPA High," is based on work by Lepeule et al. (2012) and Levy et al. (2005). EPA presents both approaches as equally valid. In Section 3 we report a "central" value estimate as the simple average of the three approaches. A critical value within each approach is the monetary value of preventing a premature mortality (or the Value of Statistical Life, VSL). Each approach is based on a VSL of approximately \$6 million (in 2000\$), which is consistent with the broader literature.

The AP2 model contains monetized benefit-per-ton estimates based on emissions in the year 2008, so damages from AP2 are scaled over time based on Census population projections (U.S. Census Bureau 2012) and per capita income growth projections used by EIA (2014), using an elasticity of the VSL to income growth consistent with NRC (2010). EPA benefit-per-ton values are developed for each year within each of three large regions by linearly extrapolating EPA's provided benefit-per-ton values. In this manner, there is implicit representation of the population and income growth assumptions incorporated in EPA's analysis. The 2015-2025 benefit-per-ton values are based on the linear trend established by EPA's 2020 and 2025 values. The 2026-2050 benefit-per-ton values are based on the linear trend established by EPA's 2025 and 2030 values. The same process is used for EPA's health incidence-per-ton (mortality and morbidity outcomes) estimates.

\subsubsection{Water usage valuation}

Due to challenges associated with quantifying the monetary value of water resource services (DOE 2015) we do not quantify the benefits of water-use reductions in monetary terms, as discussed further in section 3.4.

\section{Results}

In this section we present our electric sector scenario results and the environmental and public health benefits estimates associated with solar from the scenarios. For the scenario results, we focus on the amount and location of solar capacity and generation under the SunShot Vision scenario and the avoided generation and capacity from that scenario. Avoided generation, defined as the difference in generation between the SunShot Vision and No-New-Solar baseline scenarios, is a key determinant of the GHG, air pollution, and water benefits associated with solar. Uncertainties and limitations are also discussed.

\subsection{Scenario Results}

The SunShot Vision scenario demonstrates rapid and sustained new deployment of all solar electricity technologies. Figure 2 shows that estimated installed solar capacity reaches $319 \mathrm{GW}$ in 2030 and $708 \mathrm{GW}$ in 2050. This future solar capacity meets the $14 \%$ and $27 \%$ penetration targets in 2030 and 2050, respectively, and requires that $603 \mathrm{TWh}$ of solar energy be produced in 
2030 and 1,327 TWh in 2050. Utility-scale PV is the largest contributor to this solar energy supply, with significant but lower levels of DGPV and CSP.

\section{FIGURE 2 HERE}

The geographic distribution of solar capacity influences estimated benefits, including avoided emissions and water use. Figure 3 shows the 2050 state distribution of combined DGPV and utility PV (UPV) and CSP capacity under the SunShot Vision scenario. PV capacity is widely distributed across all 48 states modeled, although the amount of PV is higher in states with a combination of high resource quality, high electricity demand, and concentrated population densities. In contrast, CSP is restricted to eight states primarily located in the Southwest because CSP requires high levels of direct normal irradiance to generate power. Nevertheless, generation from both CSP and PV meets electricity demands throughout the entire continental United States.

\section{FIGURE 3 HERE}

The relative nationwide shares of CSP and PV are determined by the prescriptive scenario design that replicates the penetration levels in the SunShot Vision Study (DOE 2012). Deviations from these shares would yield different results in terms of location and amount of solar capacity deployed and associated environmental and health impacts.

Avoided capacity and generation are particularly important for assessing the potential environmental and health benefits associated with new solar deployment. In the scenario construct used here, avoided values refer to differences between the NNS baseline and SunShot Vision scenarios. Error! Reference source not found.Figure 4 shows avoided capacity and generation results for 2030 and 2050 over the entire continental United States footprint as estimated by ReEDS. Avoided capacity is the result of solar driving greater retirements or fewer new builds of a particular generation type in the SunShot Vision case compared to the NNS case. Avoided generation is calculated as the difference between the total annual generation of each technology type across the scenarios. Depending on the year and technology, the addition of solar leads to a reduced need for new capacity or earlier retirements of existing capacity and thereby avoids the generation that comes from this new or retired capacity. In other instances, however, solar might have little immediate impact on capacity, but can still reduce the average capacity factor of existing generators. As such, generation avoidance considers possible impacts on both existing and new generators.

In 2030, new solar in the SunShot Vision scenario is estimated to avoid 87 GW of total capacity, of which natural gas-fired capacity constitutes the majority (54 GW). Avoided 2030 generation also mostly comprises fossil sources ( $75 \%$ fossil), nearly evenly split between coal-based and natural-gas-based generation. The remaining smaller shares of 2030 avoided capacity and generation are predominantly from wind power technologies. As also shown in Figure 4, the amount of avoided fossil capacity and generation grows between 2030 and 2050; however, avoided values from non-fossil-predominantly wind - sources grow at an especially rapid pace. As a result, of the $277 \mathrm{GW}$ of avoided capacity in 2050, $159 \mathrm{GW}$ comes from wind and $102 \mathrm{GW}$ from natural gas. Similarly, wind constitutes $50 \%$ of 2050 avoided generation compared with $46 \%$ from fossil sources and the small remainder from nuclear and non-wind renewables. This 
increase in avoided wind stems directly from the modeled robust growth in wind energy, especially after 2030, and the fact that increased solar deployment places downward pressure on that growth. This result also impacts our subsequent analysis, lowering the estimated environmental and health benefits of solar in comparison to a scenario in which solar is presumed to displace more fossil generation and less wind power generation.

\section{FIGURE 4 HERE}

Note that significant uncertainties exist around the future amount and nature of avoided capacity, generation, and emissions driven by SunShot-level solar penetration. Nonetheless, the present analysis applies an electric-sector modeling approach to generate these estimates selfconsistently using the assumptions noted. Any differences in avoided values would yield potential benefits different from those presented in the following sections. For example, lower assumed natural gas prices would yield lower avoided gas generation and greater avoided coal generation, thereby increasing the environmental and public health benefits. Conversely, lower wind costs might lead to greater avoided wind generation and reduced benefits as the amount of avoided fossil usage would be lowered correspondingly. Also, our analysis extends through 2050 and does not include estimates of impacts that accrue after 2050.

\subsection{GHG reductions}

Given the results above, achieving the SunShot Vision scenario is found to reduce life-cycle GHG emissions from the power sector by $10 \%$ or 8 billion metric tons of $\mathrm{CO}_{2 \mathrm{e}}$ in total (cumulatively over 2015-2050) relative to the NNS baseline scenario (Figure 5). This represents a sizable contribution to EPA's CPP power-sector emissions targets.

\section{FIGURE 5 HERE}

Combustion-related $\mathrm{CO}_{2}$ savings (Figure 6, top) are somewhat concentrated in California, Texas, and the Southeast, due to solar deployment in these regions and by the degree to which highcarbon-emitting coal plants (and, to a lesser extent, natural gas-fired generation) are displaced. On a percentage basis (Figure 6, bottom), relative to total statewide power-sector emissions, reductions are generally spread more broadly.

Factoring in the full life cycle, total emissions reductions are somewhat lower $(8.0$ billion metric tons) than when only considering combustion ( 8.3 billion metric tons). This is largely because the sizable solar capacity additions under the SunShot Vision scenario result in higher construction-related emissions than under the NNS baseline. We have not attempted to assign the non-combustion, life-cycle emission impacts to specific regions, and so they are not included in Figure 6.

\section{FIGURE 6 HERE}

Estimates of the monetary value of these cumulative GHG emissions reductions span a large range but are sizable even in the lower case (Figure 7). Using the IWG's "central" trajectory for the SCC, discounted, present-value global climate damage reductions from the SunShot Vision scenario equal $\$ 259$ billion, equivalent to a levelized benefit of $2.2 \phi / \mathrm{kWh}$-solar. Across the full 
range of SCC estimates, total benefits span $\$ 56$ billion $(0.5 \notin / \mathrm{kWh}$-solar) to $\$ 789$ billion $(6.8 \phi / \mathrm{kWh}-$ solar). If, alternatively, solar is viewed as a way to meet future carbon-reduction requirements, then the present-value benefits of achieving the SunShot Vision scenario range from $\$ 60$ billion to $\$ 92$ billion $(0.5-0.8 \notin / \mathrm{kWh}$-solar) when only considering EPA CPP estimates, and from $\$ 142$ billion to $\$ 347$ billion (1.2-3.0ф/kWh-solar) when considering Synapse's longerterm carbon-reduction policy possibilities.

\section{FIGURE 7 HERE}

We do not consider in these estimates the possible erosion of the GHG (or air pollutant) emissions benefits due to the increased cycling, ramping, and part loading required of fossil generators in electric systems with higher penetrations of variable renewable generation, as these impacts are not fully considered in ReEDS. This omission will not meaningfully bias our results, however, because the available literature demonstrates that this impact is relatively small (Göransson and Johnsson 2009; Gross et al. 2006; Pehnt et al. 2008; Perez-Arriaga and Batlle 2012; Oates and Jaramillo 2013; Valentino et al. 2012; GE Energy Consulting 2014; Lew et al. 2013).

\subsection{Air pollution reductions}

Achieving the SunShot Vision scenario is also found to reduce national power sector emissions of $\mathrm{SO}_{2}, \mathrm{NO}_{\mathrm{x}}$, and $\mathrm{PM}_{2.5}$ by $9 \%, 11 \%$, and $8 \%$ in total (cumulatively over 2015-2050) relative to the NNS baseline scenario (Figure 8).

The emissions savings are spread widely across the United States but with some concentration in Texas, Oklahoma, Louisiana, Arkansas, and the broader Southeastern region (see Figure 9).

These results are driven both by the amount of solar deployment in each state and by the regions in which high-emitting coal generation is displaced.

\section{FIGURE 8 HERE}

\section{FIGURE 9 HERE}

These emissions reductions lead to improved air quality and health outcomes across the continental United States. The cumulative value of U.S. health and air quality benefits from the SunShot Vision scenario ranges from \$77-\$298 billion on a discounted, present-value basis. The average "central" estimate equals $\$ 167$ billion, or $1.4 \varnothing / \mathrm{kWh}$-solar on a levelized basis; the total 
range is $0.7-2.6 \notin / \mathrm{kWh}$-solar (Figure 10

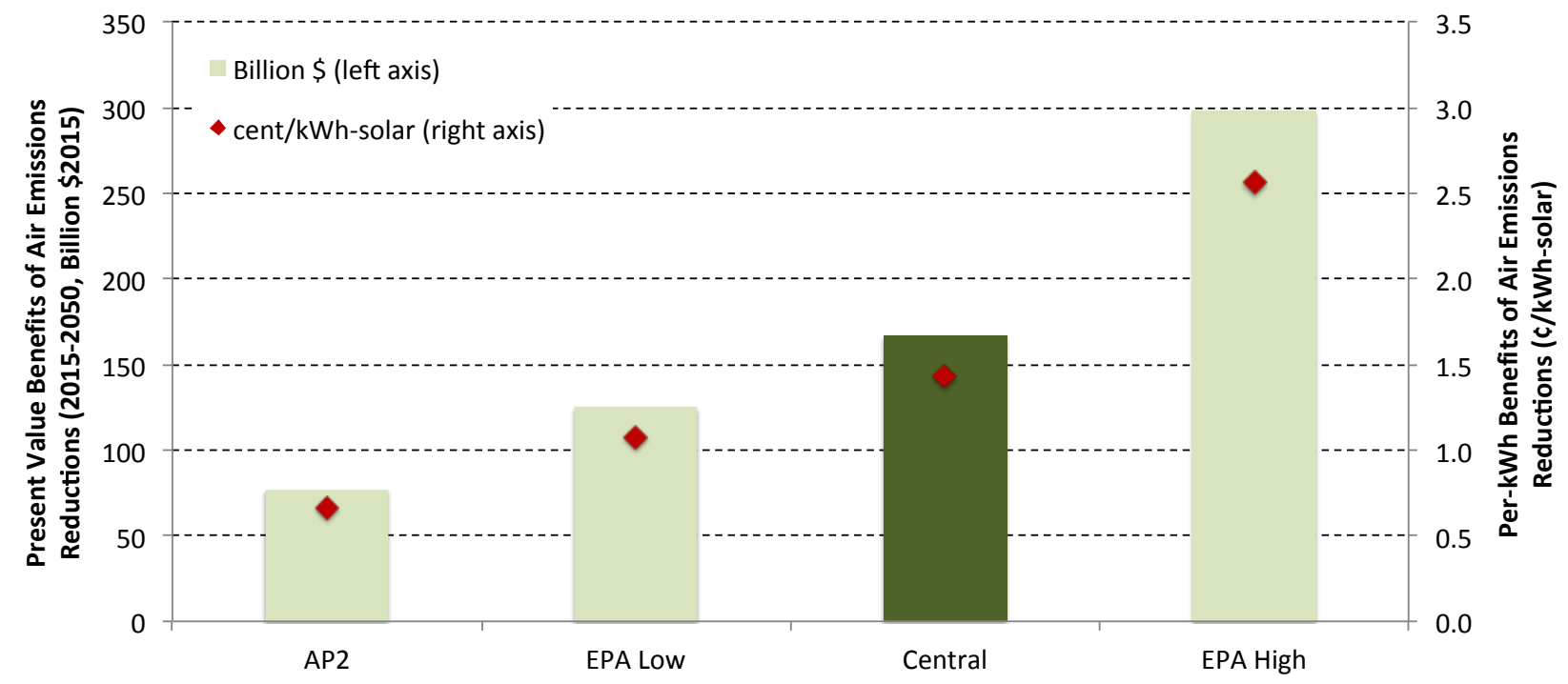

Figure 1). The range of benefits estimates reflects uncertainties in how to value emissions reductions, but the benefits are sizable even under the lowest AP2 estimate.

\section{FIGURE 10 HERE}

Reduction of $\mathrm{SO}_{2}$ and the subsequent reduction of particulate sulfate concentrations account for most of the monetized benefits. For example, reduced $\mathrm{SO}_{2}$ emissions accounted for $61 \%, 73 \%$, and $68 \%$ of the AP2, EPA Low, and EPA High benefit estimates, respectively. The benefits of reduced tropospheric ozone (due to reduced $\mathrm{NO}_{\mathrm{x}}$ emissions) were relatively small, accounting for $7 \%$ and $14 \%$ of the EPA Low and High benefit estimates, respectively. Note that a disaggregated estimate of ozone benefits was not available from the AP2 model. Clearly, exposure to particulates (directly or indirectly from emissions of $\mathrm{SO}_{2}, \mathrm{NO}_{\mathrm{x}}$ and $\mathrm{PM}_{2.5}$ ) is the primary driver of monetized health outcomes.

Most of the monetized health benefits come from avoided premature mortality. Based on the EPA approach, achieving the SunShot Vision scenario prevents 25,000-59,000 premature mortalities in total from 2015 to 2050 . Achieving the SunShot Vision scenario also would result in numerous forms of avoided morbidity outcomes (Table 1), including 30,800 hospital admissions for respiratory and cardiovascular symptoms, 2.5 million lost work days, and 2.5 million missed school days.

\section{TABLE 1 HERE}

These estimates include a subset — and arguably the most important — emissions impacts. Due to methodological and data limitations, we do not evaluate impacts from heavy metal releases, radiological releases, waste products, and land-use impacts associated with power and upstream fuel production as well as noise, aesthetics, and others. EPA (2015c) includes a discussion of these additional environmental and public health impacts deriving from power sector emissions that are not quantified in EPA analyses or in our analysis. Moreover, we only consider emissions from power plant operations, and so do not assess upstream and downstream life-cycle impacts. 
The marginal impacts of air pollutant emissions on health outcomes are an area of active research, and we reflect some of this uncertainty by calculating benefits with both the AP2 and EPA CPP methods. Our methodology presumes MATS is maintained or replaced with a similar regulation such that $\mathrm{SO}_{2}$ and $\mathrm{NO}_{\mathrm{x}}$ cap-and-trade programs, such as CSAPR, are essentially nonbinding over time: otherwise, the benefits of achieving the SunShot Vision scenario should arguably be valued at allowance prices to reflect savings in the cost of complying with the cap (Siler-Evans et al. 2013). It is also possible that we may not incorporate some more-localized existing binding cap-and-trade programs; however, the geographic extent of these programs is limited, so they will not substantially bias our results. 


\subsection{Water use reductions}

On a national level, power-sector water withdrawals decline considerably over time under both the SunShot Vision and NNS baseline scenarios, largely due to replacement and reduced operations of the once-through-cooled thermal facilities (Figure 11). In the NNS baseline scenario, once-through-cooled plants are largely replaced by new thermal plants using recirculating cooling and wind power capacity. In the SunShot Vision scenario, water-intensive plants are also replaced by solar energy. As a result, national powersector withdrawals are 4\% lower (46 trillion gallons ) on a cumulative basis from 20152050 in the SunShot Vision scenario than in the NNS baseline scenario. In comparison to 2015 values, SunShot Vision scenario water withdrawals are 68\% lower in 2050.

\section{FIGURE 11 HERE}

National power-sector water consumption declines over time in both scenarios (Figure 12), but to a lesser extent than water withdrawals. Consumption decreases sooner and more significantly in the SunShot Vision scenario. While the replacement of oncethrough cooling with recirculating cooling reduces water withdrawals, it increases water consumption in the NNS baseline scenario, thus delaying the decrease in water consumption relative to water withdrawals. In the SunShot Vision scenario, the greater penetration of solar energy counteracts some of the effects of the adoption of recirculating cooling and reduces water consumption for the sector as a whole. Overall, national power-sector consumption is $9 \%$ lower (5 trillion gallons) on a cumulative basis from 2015-2050 in the SunShot Vision scenario than in the NNS baseline scenario. In comparison to 2015 values, SunShot Vision scenario consumption is $28 \%$ lower in 2050.

\section{FIGURE 12 HERE}

Water withdrawal and consumption impacts under the SunShot Vision vary by state (Figure 13). By 2050, 35 of 48 states have lower withdrawals in the SunShot Vision scenario than in the NNS baseline scenario, a reflection of where solar capacity is deployed and where the most water-intensive thermal plants are offset. The largest water withdrawal reductions are seen in Texas, Louisiana, Florida, and California, with substantial reductions seen in the Southwest, Southeast, Central, and Mid-Atlantic regions. For water consumption, by 2050, 36 of 48 states have lower consumption in the SunShot Vision scenario than in the NNS baseline scenario. States with the largest consumption savings include California, Texas, Arkansas, and Florida, with substantial reductions seen in the Southwest, Southeast, and Mid-Atlantic regions. As a result of ReEDS' electric-sector capacity additions and operational simulations, some states see slight increases in water withdrawals and/or consumption in the SunShot Vision scenario relative to the NNS baseline scenario. These states are located in regions that are historically not as drought prone as the states that are estimated to have reductions in water usage. 


\section{FIGURE 13 HERE}

We have assumed that all new CSP plants are deployed with dry-cooling technologies. To evaluate the robustness of these impacts to different assumptions about CSP cooling, we considered a scenario in which new CSP capacity is built with equal shares of dry cooling, wet cooling, and hybrid wet-dry cooling systems. Because wet-cooled CSP systems are assumed to use recirculating cooling, whether wet, dry, or hybrid cooling is used has a larger impact on consumption than on withdrawals; we therefore focus on consumption impacts. Of the eight states with CSP deployment, Arizona, Colorado, Florida, Nevada, Texas, and Utah still show lower levels of water consumption in 2050 under the SunShot cooling-sensitivity scenario than under the NNS baseline scenarioCalifornia and New Mexico are the exceptions, although New Mexico's water consumption under the sensitivity scenario is still lower than its consumption in 2015. California's increased consumption is largely due to its relatively low levels of consumption in 2015 and the transition of once-through-cooled thermal generators on the coast to inland-based generation using freshwater. Ocean water resource impacts are not modeled in this analysis because there is not yet data on ocean water availability and cost consistent with other water resources modeled in ReEDS. Relatively high levels of modeled CSP deployment in California indicate that CSP cooling system decisions can affect state-level power-sector water use. That said, on a national basis, 2050 water withdrawals remain 5\% lower in the SunShot cooling-sensitivity scenario than in the NNS baseline scenario, and 2050 water consumption is $12 \%$ lower, demonstrating that significant national water-use reductions are anticipated even if dry cooling is not deployed in all cases.

The water savings found in the SunShot Vision scenario provide economic and environmental benefits, especially in regions where water is limited and could be used for other ecosystem or societal services. Reducing electric sector dependence on water can also help ease concerns over energy sector vulnerabilities to climate change (DOE 2013 describes relevant concerns related to climate change impacts on both water availability and water temperature). The lower life-cycle water requirements of solar energy technologies, meanwhile, can help alleviate other energy-sector impacts on water resource quality and quantity that occur during upstream fuel production for other technologies (Averyt et al. 2011).

There is no standard, literature-based methodology to quantify the monetary benefits of these water-use reductions. ReEDS already considers cost and performance characteristics of different cooling technologies as well as the availability and cost of water supply in its optimization; these costs and considerations are embedded in the ReEDS decision-making and resultant deployment impacts. However, if future water resources become more limited or future policy becomes more restrictive, then additional costs might be incurred. To assess additional costs in this case we look at the cost of replacing wet cooling with dry cooling. Dry cooling adds capital expense to thermal plants and reduces plant efficiencies and is estimated to increase levelized cost of electricity by $0.32-0.64 \notin / \mathrm{kWh}$ for coal generation (Zhai and Rubin 2010 ) and by $\$ 3.8-$ $\$ 6.8$ per 1,000 gallons (Maulbetsch and DiFilippo 2006), corresponding to approximately $0.06-0.17 \phi / \mathrm{kWh}$ (DOE 2015) for natural gas combined cycle plants. 
Dry cooling costs likely set an upper bound on the water-related cost-savings of solar energy. Many regions of the country are not facing water scarcity, so the economic benefits of reduced water use are geographically limited. Also, to the extent that solar offsets more electricity supply (kilowatt-hours) than electricity capacity (kilowatts), it may not be able to offset the full capital and operating cost of less water-intensive cooling technologies. To date few plants have been required or chosen to implement dry cooling; alternative, lower-cost means of obtaining and/or reducing water have predominated, including simply locating plants where water is available. Alternative water resources, such as municipal wastewater or shallow brackish groundwater, could also be more cost effective than dry cooling in some regions (Tidwell et al. 2014). These lower-cost methods of reducing water use are likely to dominate for the foreseeable future.

\section{Conclusion}

We use a scenario-analysis approach to assess key potential environmental and health benefits of achieving the solar penetrations envisioned by DOE (2012). Specifically, we compare a 14\%-by-2030 and 27\%-by-2050 "SunShot Vision" scenario to a "NNS baseline" scenario (which deploys no new solar after 2014) over the 2015-2050 period. Given the appropriate caveats, described throughout this work, we find that a future U.S. electricity system in which solar plays a major role could result in enduring environmental and health benefits globally, nationally, and locally. Figure 14 presents a summary of these results.

\section{FIGURE 14 HERE}

We find that solar power reduces GHG and air pollutants by 10\%, from 2015-2050, providing a discounted present value of $\$ 56-\$ 789$ billion (central value of $\sim \$ 250$ billion, equivalent to $\sim 2 \phi / \mathrm{kWh}$-solar) in climate benefits and $\$ 77-\$ 298$ billion (central value of $\$ 167$ billion, or $\sim 1.4 \phi / \mathrm{kWh}$-solar) in air quality and public health benefits. The ranges reflect uncertainty within the primary literature about the marginal impact of emissions of GHG and air pollutants. Solar power is also found to reduce water withdrawals and consumption by $4 \%$ and $9 \%$, respectively, including in many drought-prone and arid states. Additional uncertainty on future technology and market conditions exists and would change the amount and type of avoided generation - thereby affecting the possible range of benefits estimated herein. Furthermore, GHG, air pollutant, and water reduction estimates are uncertain owing to the impact of uncertain policy factors on those reductions. Simply put, the more stringent the underlying emissions or water-use regulations, the smaller the opportunity is for solar to reduce those impacts.

Prior literature indicates that these benefits might be achieved most efficiently if policies were adopted to directly internalize the environmental costs into electric sector markets (Borenstein 2012; Edenhofer et al. 2013; Fischer and Newell 2008; Fell and Linn 2013; IPCC 2011; IPCC 2014; Kalkuhl et al. 2013; McKibbin et al. 2014; Novan 2014; Rausch and Karplus 2014; Tuladhar et al. 2014). Our work, however, is not an evaluation of a specific policy but is instead intended to assess the potential benefits of future solar deployment resulting from the stated cost reductions. We calculate these benefits 
assuming no major market or policy changes. Thus, this work suggests that if policies designed to internalize environmental costs are not fully implemented, low cost solar power could provide important environmental benefits through the next decades.

\section{Acknowledgements}

For their support of this study, the authors thank the entire U.S. Department of Energy (DOE) Solar Energy Technologies Office team. Lawrence Berkeley National Laboratory's contributions to this paper were funded by DOE's Solar Energy Technologies Office, Office of Energy Efficiency and Renewable Energy under Contract No. DE-AC02-05CH11231. National Renewable Energy Laboratory's contributions to this paper were funded by DOE's Solar Energy Technologies Office, Office of Energy Efficiency and Renewable Energy under Contract No. DE-AC36-08GO28308.

\section{References}

Arent, D., J. Pless, T. Mai, R. Wiser, M. Hand, S. Baldwin, G. Heath, J. Macknick, M. Bazilian, A. Schlosser, and P. Denholm. 2014. "Implications of High Renewable Electricity Penetration in the US for Water Use, Greenhouse Gas Emissions, Land-Use, and Materials Supply.” Applied Energy 123: 368-77.

Averyt, K., J. Fisher, A. Huber-Lee, A. Lewis, J. Macknick, N. Madden, J. Rogers, and S. Tellinghuisen. 2011. Freshwater Use by U.S. Power Plants: Electricity's Thirst for a Precious Resource. Cambridge, MA: Union of Concerned Scientists.

Averyt, K., J. Macknick, J. Rogers, N. Madden, J. Fisher, J. Meldrum, and R. Newmark. 2013. "Water Use for Electricity in the United States: An Analysis of Reported and Calculated Water Use Information for 2008." Environmental Research Letters 8 (015001).

Barbose, G., N. Darghouth, D. Millstein, M. Spears, R.H. Wiser, M. Buckley, R. Widiss, and N. Grue. 2015. Tracking the Sun VIII: An Historical Summary of the Installed Price of Photovoltaics in the United States from 1998-2014. Berkeley, CA: Lawrence Berkeley National Laboratory.

Barbose, G., R. Wiser, A. Phadke, and C. Goldman. 2008. "Managing Carbon Regulatory Risk in Utility Resource Planning: Current Practices in the Western United States." Energy Policy 36(9): 3300-11.

Bell M.L., A. McDermott, S.L. Zeger, J.M. Samet, and F. Dominici. 2004. "Ozone and Short-Term Mortality in 95 US Urban Communities, 1987-2000.” Journal of the American Medical Association 292(19): 2372-78.

Bird, L., C. Chapman, J. Logan, J. Sumner, and W. Short. 2011. "Evaluating Renewable Portfolio Standards and Carbon Cap Scenarios in the U.S. Electric Sector." Energy Policy 39(5): 2573-85.

Bolinger, M., and J. Seel. 2015. Utility-Scale Solar 2014: An Empirical Analysis of Project Cost, Performance, and Pricing Trends in the United States. Berkeley, CA: Lawrence Berkeley National Laboratory. 
Borenstein, S. 2012. "The Private and Public Economics of Renewable Electricity Generation." Journal of Economic Perspectives 26(1): 67-92.

Buonocore, J., P. Luckow, G. Norris, J. Spengler, B. Biewald, J. Fisher, and J. Levy. 2016. "Health and Climate Benefits of Different Energy-Efficiency and Renewable Energy Choices." Nature Climate Change 6, 100-105.

Cai, H., M. Wang, A. Elgowainy, and J. Han. 2012. Updated Greenhouse Gas and Criteria Air Pollutant Emission Factors and Their Probability Distribution Functions for Electric Generating Units. ANL/ESD/12-2. Lemont, IL: Argonne National Laboratory.

Cai, H., M. Wang, A. Elgowainy, and J. Han. 2013. Updated Greenhouse Gas and Criteria Air Pollutant Emission Factors of the U.S. Electric Generating Units in 2010. Lemont, IL: Argonne National Laboratory.

Callaway, D., M. Fowlie, and G. McCormick. 2015. Location, location, location: The variable value of renewable energy and demand-side efficiency resources. Berkeley, CA: Energy Institute at Haas.

Chung, D., K. Horowitz, and P. Kurup. 2016. On the Path to SunShot: Emerging Opportunities and Challenges in U.S. Solar Manufacturing. Golden, CO: National Renewable Energy Laboratory. NREL/TP-7A40-65788.

Clemmer, S., J. Rogers, S. Sattler, J. Macknick, and T. Mai. 2013. "Modeling LowCarbon US Electricity Futures to Explore Impacts on National and Regional Water Use." Environmental Research Letters 8 (015004).

Cole, W., T. Mai, K. Eurek, D. Steinberg, and R. Margolis. 2015. "Considering the Role of Solar Generation under Rate-Based Targets in the EPA's Proposed Clean Power Plan." The Electricity Journal 28(8):20-28.

Cullen, J. 2013. "Measuring the Environmental Benefits of Wind-Generated Electricity." American Economic Journal: Economic Policy 5(4): 107-33.

Denholm, P., E. Drury, and R. Margolis. 2009. The Solar Deployment System (SolarDS) Model: Documentation and Sample Results. NREL/TP-6A2-45832. Golden, CO:

National Renewable Energy Laboratory.

Denholm, P., M.M. Hand, T. Mai, R. Margolis, G. Brinkman, E. Drury, M. Mowers, and C. Turchi. 2012. Potential Role of Concentrating Solar Power in Enabling High Renewables Scenarios in the United States. NREL/TP-6A20-56294. Golden, CO: National Renewable Energy Laboratory.

Denholm, P., K. Clark, and M. O'Connell. 2016. On the Path to SunShot: Emerging Issues and Challenges in Integrating High Levels of Solar into the Electrical Generation and Transmission System. Golden, CO: National Renewable Energy Laboratory. NREL/TP-6A20-65800. 
DOE (U.S. Department of Energy). 2008. 20\% Wind Energy by 2030: Increasing Wind Energy's Contribution to U.S. Electricity Supply. DOE/GO-102008-2567. Washington, DC: U.S. Department of Energy.

DOE. 2012. "SunShot Vision Study." Washington, DC: U.S. Department of Energy. DOE/GO-102012-3037.

DOE. 2013. U.S. Energy Sector Vulnerabilities to Climate Change and Extreme Weather. DOE/PI-0013. Washington, DC: U.S. Department of Energy.

DOE. 2015. Wind Vision: A New Era for Wind Power in the United States. DOE/GO102015-4557. Washington, DC: U.S. Department of Energy.

Driscoll, C.T., J.J. Buonocore, J.I. Levy, K.F. Lambert, D. Burtraw, S.B. Reid, H. Fakhraei, and J. Schwartz. 2015. "US Power Plant Carbon Standards and Clean Air and Health Co-Benefits." Nature Climate Change 5: 535-40.

Edenhofer, O., L. Hirth, B. Knopf, M. Pahle, S. Schlömer, E. Schmid, and F. Ueckerdt. 2013. "On the Economics of Renewable Energy Sources." Energy Economics 40, Supplement 1 (December): S12-S23.

EIA (U.S. Energy Information Administration). 2014. Annual Energy Outlook 2014 with Projections to 2040. DOE/EIA-0383(2014). Washington, DC: U.S. Department of Energy.

EIA (U.S. Energy Information Administration). 2015a. Annual Energy Outlook 2015 with Projections to 2040. DOE/EIA-0383(2015). Washington, DC: U.S. Department of Energy.

EPA (U.S. Environmental Protection Agency). 2009. Cooling Water Intake StructuresCWA 316(b), Phase II-Large Existing Electric Generating Plants. Washington, DC: U.S. Environmental Protection Agency.

EPA (U.S. Environmental Protection Agency). 2011. Regulatory Impact Analysis for the Final Mercury and Air Toxics Standards. Docket ID EPA-452/R-11-011. Research Triangle Park, NC: U.S. Environmental Protection Agency.

EPA (U.S. Environmental Protection Agency). 2015a. Carbon Pollution Emission Guidelines for Existing Stationary Sources: Electric Utility Generating Units. Washington, DC: U.S. Environmental Protection Agency.

EPA (U.S. Environmental Protection Agency). 2015b. Standards of Performance for Greenhouse Gas Emissions from New, Modified, and Reconstructed Stationary Sources: Electric Utility Generating Units. Washington, DC: U.S. Environmental Protection Agency. 
EPA (U.S. Environmental Protection Agency). 2015c. Regulatory Impact Analysis for the Clean Power Plan Final Rule. Docket ID EPA-452/R-15-003. Research Triangle Park, NC: U.S. Environmental Protection Agency.

EPIA (European Photovoltaic Industry Association). 2014. Global Market Outlook for Photovoltaics: 2014-2018. Brussels, Belgium: European Photovoltaic Industry Association.

Eurek, K., P. Denholm, R. Margolis, and M. Mowers. 2013. Sensitivity of Utility-Scale Solar Deployment Projections in the SunShot Vision Study to Market and Performance Assumptions. NREL/TP-6A20-55836. Golden, CO: National Renewable Energy Laboratory.

Fann, N., K.R Baker, and C.M. Fulcher. 2012. "Characterizing the PM2.5-Related Health Benefits of Emission Reductions for 17 Industrial, Area and Mobile Emission Sectors Across the U.S.” Environment International 49: 141-51.

Fell, H. and J. Linn. 2013. "Renewable Electricity Policies, Heterogeneity, and Cost Effectiveness." Journal of Environmental Economics and Management 66(3): 688-707.

Fischer, C. and R.G. Newell. 2008. "Environmental and Technology Policies for Climate Mitigation.” Journal of Environmental Economics and Management 55(2): 142-62.

GAO (U.S. Government Accountability Office). 2014. Regulatory Impact Analysis: Development of Social Cost of Carbon Estimates. GAO-14-663. Washington, DC: U.S. Government Accountability Office.

GE Energy Consulting. 2014. PJM Renewable Integration Study. Schenectady, NY: General Electric Energy Consulting Group. Report for PJM Interconnection.

Göransson, L., and F. Johnsson. 2009. "Dispatch Modeling of a Regional Power Generation System - Integrating Wind Power.” Renewable Energy 34(4): 1040-49.

Graff Zivin, J.S., M.J. Kotchen, and E. Mansur. 2014. "Spatial and Temporal Heterogeneity of Marginal Emissions: Implications for Electric Cars and Other Electricity-Shifting Policies. "Journal of Economic Behavior \& Organization 107: 24868.

Gross, R., P. Heptonstall, D. Anderson, T. Green, M. Leach, and J. Skea. 2006. The Costs and Impacts of Intermittency: An Assessment of the Evidence on the Costs and Impacts of Intermittent Generation on the British Electricity Network. Imperial College London: UK Energy Research Centre (UKERC).

GTM/SEIA. 2015. U.S. Solar Market Insight Report: 2014 Year in Review. Washington, DC: GTM Research and Solar Energy Industries Association. 
IPCC (Intergovernmental Panel on Climate Change). 2011. Special Report on Renewable Energy Sources and Climate Change Mitigation (SRREN). Cambridge, UK: Cambridge University Press.

IPCC (Intergovernmental Panel on Climate Change). 2014. Climate Change 2014: Mitigation of Climate Change: Working Group III Contribution to the Fifth Assessment Report of the IPCC. Cambridge, UK: Cambridge University Press.

IWG (U.S. Interagency Working Group on the Social Cost of Carbon). 2010. Technical Support Document: Social Cost of Carbon for Regulatory Impact Analysis under Executive Order 12866. Washington, DC: U.S. Interagency Working Group on the Social Cost of Carbon.

IWG (U.S. Interagency Working Group on the Social Cost of Carbon). 2015. Technical Support Document: Technical Update of the Social Cost of Carbon for Regulatory Impact Analysis under Executive Order 12866. July 2015 Revision. Washington, DC: U.S. Interagency Working Group on the Social Cost of Carbon.

Johnson, L., S. Yeh, and C. Hope. 2013. "The Social Cost of Carbon: Implications for Modernizing Our Electricity System." Journal of Environmental Studies and Sciences 3(4): 369-75.

Kaffine, D., B. McBee, and J. Lieskovsky. 2013. "Emissions Savings from Wind Power Generation in Texas." The Energy Journal 34(1): 155-75.

Kalkuhl, M., O. Edenhofer, and K. Lessman. 2013. "Renewable Energy Subsidies: Second-Best Policy or Fatal Aberration for Mitigation?" Resource and Energy Economics 35(3): 217-34.

Kopp, R.E., and B.K. Mignone. 2012. “The U.S. Government's Social Cost of Carbon Estimates after Their First Two Years: Pathways for Improvement." Economics: The Open-Access, Open-Assessment E-Journal 6(2012-15): 1-41.

Krewski, D., M. Jerrett, R.T. Burnett, R. Ma, E. Hughes, Y. Shi, M.C. Turner, C.A. Pope, G. Thurston, E.E. Calle, M.J. Thun, B. Beckerman, P. DeLuca, N. Finkelstein, K. Ito, D.K. Moore, K.B. Newbold, T. Ramsay, Z. Ross, H. Shin, and B. Tempalski. 2009. Extended Follow-Up and Spatial Analysis of the American Cancer Society Study Linking Particulate Air Pollution and Mortality. Research Report (Health Effects Institute) 140: 5-114.

Lantz, E., D. Steinberg, M. Mendelsohn, O. Zinaman, T. James, G. Porro, M. Hand, T. Mai, J. Logan, J. Heeter, and L. Bird. 2014. Implications of a PTC Extension on U.S. Wind Deployment. NREL/TP-6A20-61663. Golden, CO: National Renewable Energy Laboratory.

Lepeule, J., F. Laden, D. Dockery, and J. Schwartz. 2012. "Chronic Exposure to Fine Particles and Mortality: An Extended Follow-Up of the Harvard Six Cities Study from 1974 to 2009." Environmental Health Perspectives 120: 965-70. 
Levy, J.I., S.M. Chemerynski, and J.A. Sarnat. 2005. "Ozone Exposure and Mortality: An Empiric Bayes Metaregression Analysis.” Epidemiology 16(4): 458-68.

Lew, D., G. Brinkman, E. Ibanez, A. Florita, M. Heaney, B.-M. Hodge, M. Hummon, G. Stark, J. King, and S.A. Lefton. 2013. The Western Wind and Solar Integration Study Phase 2. NREL/TP-5500-55588. Golden, CO: National Renewable Energy Laboratory.

Logan, J., A. Lopez, T. Mai, C. Davidson, M. Bazilian, and D. Arent. 2013. "Natural Gas Scenarios in the U.S. Power Sector.” Energy Economics 40: 183-95.

Luckow, P., E. Stanton, S. Fields, B. Biewald, S. Jackson, J. Fisher, and R. Wilson. 2015. 2015 Carbon Dioxide Price Forecast. Cambridge, MA: Synapse Energy Economics, Inc.

Macknick, J., S. Cohen, V. Tidwell, R. Newmark, A. Martinez, and P. Sullivan. 2015. Water Constraints in an Electric Sector Capacity Expansion Model. NREL/TP-6A2064270. Golden, CO: National Renewable Energy Laboratory.

Macknick, J., S. Sattler, K. Averyt, S. Clemmer, and J. Rogers. 2012. “The Water Implications of Generating Electricity: Water Use across the United States Based on Different Electricity Pathways through 2050." Environmental Research Letters 7(4): 045803.

Mai, T., D. Mulcahy, M.M. Hand, and S. Baldwin. 2014. "Envisioning a Renewable Electricity Future for the United States.” Energy 65: 374-86.

Mai, T., C. Wesley, E. Lantz, C. Marcy, and B. Sigrin. 2016. Impacts of Federal Tax Credit Extensions on Renewable Deployment and Power Sector Emissions. NREL/TP6A20-65571. Golden, CO: National Renewable Energy Laboratory.

Maulbetsch, J.S., and M.N. DiFilippo. 2006. Cost and Value of Water Use at CombinedCycle Power Plants. CEC-500-2006-034. Sacramento, CA: California Energy

Commission.

McKibbin, W.J., A.C. Morris, and P.J. Wilcoxen. 2014. "Pricing Carbon in the U.S.: A Model-Based Analysis of Power-Sector-Only Approaches.” Resource and Energy Economics 36(1): 130-50.

McCubbin, D., and B.K. Sovacool. 2013. "Quantifying the Health and Environmental Benefits of Wind Power to Natural Gas." Energy Policy 53(February): 429-41.

Meldrum, J., S. Nettles-Anderson, G. Heath, and J. Macknick. 2013. "Life Cycle Water Use for Electricity Generation: A Review and Harmonization of Literature Estimates." Environmental Research Letters 8: 015031.

Mignone, B.K., T. Alfstad, A. Bergman, K. Dubin, R. Duke, P. Friley, A. Martinez, M. Mowers, K. Palmer, A. Paul, S. Showalter, S. Steinberg, M. Woerman, and F. Wood. 2012. "Cost-Effectiveness and Economic Incidence of a Clean Energy Standard." Economics of Energy \& Environmental Policy 1(3): 59-86. 
Muller, N.Z., R. Mendelsohn, and W. Nordhaus. 2011. "Environmental Accounting for Pollution in the United States Economy." American Economic Review 101(5): 1649-75.

Novan, K. 2014. Valuing the Wind: Renewable Energy Policies and Air Pollution Avoided. Working paper. Davis, CA: University of California, Davis.

NRC (National Research Council). 2010. Hidden Costs of Energy: Unpriced

Consequences of Energy Production and Use. National Research Council of the National Academies. Washington, DC: National Academies Press.

NREL (National Renewable Energy Laboratory). 2012. Renewable Electricity Futures Study. M.M. Hand, S. Baldwin, E. DeMeo, J.M. Reilly, T. Mai, D. Arent, G. Porro, M. Meshek, and D. Sandor, editors. 4 vols. NREL/TP-6A20-52409. Golden, CO: National Renewable Energy Laboratory.

Oates, D.L., and P. Jaramillo. 2013. "Production Cost and Air Emissions Impacts of Coal Cycling in Power Systems with Large-Scale Wind Penetration." Environmental Research Letters 8(2): 024022.

Palmintier, B., R. Broderick, B. Mather, M. Coddington, K. Baker, F. Ding, M. Reno, M. Lave, and A. Bharatkumar. 2016. On the Path to SunShot: Emerging Issues and Challenges in Integrating Solar with the Distribution System. Golden, CO: National Renewable Energy Laboratory. NREL/TP-5D00-65331.

Pehnt, M., M. Oeser, and D.J. Swider. 2008. "Consequential Environmental System Analysis of Expected Offshore Wind Electricity Production in Germany." Energy 33(5): 747-59.

Perez-Arriaga, I.J., and C. Batlle. 2012. "Impacts of Intermittent Renewables on Electricity Generation System Operation.” Economics of Energy \& Environmental Policy $1(2)$.

Peters, A., D.W. Dockery, J.E. Muller, and M.A. Mittleman. 2001. "Increased Particulate Air Pollution and the Triggering of Myocardial Infraction." Circulation 103: 2810-2815.

Rausch, S., and V. Karplus. 2014. "Markets versus Regulation: The Efficiency and Distributional Impacts of U.S. Climate Policy Proposals.” The Energy Journal 35(SI1):199-227.

Rogers, J., K. Averyt, S. Clemmer, M. Davis, F. Flores-Lopez, D. Kenney, J. Macknick, N. Madden, J. Meldrum, S. Sattler, E. Spanger-Siegfried, and D. Yates. 2013. WaterSmart Power: Strengthening the U.S. Electricity System in a Warming World. Cambridge, MA: Union of Concerned Scientists.

Sarzynski, A., J. Larrieu, and G. Shrimali. 2012. "The Impact of State Financial Incentives on Market Deployment of Solar Technology." Energy Policy 46(0): 550-57. 
Shindell, D. 2015. “The Social Cost of Atmospheric Release." Climatic Change 130(2): $313-26$.

Short, W., P. Sullivan, T. Mai, M. Mowers, C. Uriarte, N. Blair, D. Heimiller, and A. Martinez. 2011. Regional Energy Deployment System (ReEDS). NREL/TP-6A20-46534. Golden, CO: National Renewable Energy Laboratory.

Shrimali, G., and S. Jenner. 2013. "The Impact of State Policies on Deployment and Cost of Solar PV in the US: A Sector Specific Empirical Analysis." Renewable Energy 60: $679-90$.

Sigrin, B., P. Sullivan, E. Ibanez, and R. Margolis. 2014. Representation of Solar Capacity Value in the ReEDS Capacity Expansion Model. NREL/TP-6A20-61182. Golden, CO: National Renewable Energy Laboratory.

Siler-Evans, K., I.M. Azevedo, M.G. Morgan, and J. Apt. 2013. "Regional Variations in the Health, Environmental, and Climate Benefits of Wind and Solar Generation." Proceedings of the National Academy of Sciences 110(29): 11768-73.

Sinha, P., M. de Wild-Scholten, A. Wade, and C. Breyer. 2013. "Total Cost Electricity Pricing of Photovoltaics." $28^{\text {th }}$ European Photovoltaic Solar Energy Conference, Paris, France.

Sullivan, P., W. Cole, N. Blair, E. Lantz, V. Krishnan, T. Mai, D. Mulcahy, and G. Porro. 2015. 2015 Standard Scenarios Annual Report: U.S. Electric Sector Scenario Exploration. NREL/TP-6A20-64072. Golden, CO: National Renewable Energy Laboratory.

Sullivan, P., C. Uriarte, and W. Short. 2014. "Greenhouse Gas Mitigation Options in the U.S. Electric Sector: A ReEDS Analysis.” Energy Journal 35(SI1): 101-14.

Tidwell, V.C., J. Macknick, K. Zemlick, J. Sanchez, and T. Woldeyesus. 2014. "Transitioning to Zero Freshwater Withdrawal in the U.S. for Thermoelectric Generation.” Applied Energy 131: 508-16.

Tidwell, V.C., L.A. Malczynski, P.H. Kobos, G.T. Klise, and E. Shuster. 2013. "Potential Impacts of Electric Power Production Utilizing Natural Gas, Renewables and Carbon Capture and Sequestration on U.S. Freshwater Resources." Environmental Science and Technology 47: 8940-47.

Tuladhar, S., S. Mankowski, and P. Bernstein. 2014. "Interaction Effects of MarketBased and Command-and-Control Policies." The Energy Journal 35(SI1):61-88.

Turchi, C.S., M.J. Wagner, and C.F. Kutscher. 2010. Water Use in Parabolic Trough Power Plants: Summary Results from WorleyParsons' Analyses. NREL/TP-5500-49468. Golden, CO: National Renewable Energy laboratory. 
UCS (Union of Concerned Scientists). 2012. UCS EW3 Energy-Water Database. V.1.3. Cambridge, MA: Union of Concerned Scientists.

U.S. Census Bureau. 2012. 2012 National Population Projections Summary Tables, Table 1. Projections of the Population and Components of Change for the United States: 2015 to 2060. Washington, DC: U.S. Census Bureau Population Division.

Valentino, L., V. Valenzuela, A. Botterud, Z. Zhou, and G. Conzelmann. 2012. "SystemWide Emissions Implications of Increased Wind Power Penetration." Environmental Science \& Technology 46(7): 4200-206.

Woodhouse, M., R. Jones-Albertus, D. Feldman, R. Fu, K. Horowitz, D. Chung, D. Jordan, and S. Kurtz. 2016. On the Path to SunShot: The Role of Advancements in Solar Photovoltaic Efficiency, Reliability, and Costs. Golden, CO: National Renewable Energy Laboratory. NREL/TP-6A20-65464.

Ventyx. (2013). Ventyx Energy Velocity Suite.

Zhai, H., and E.S. Rubin. 2010. "Performance and Cost of Wet and Dry Cooling Systems for Pulverized Coal Power Plants with and Without Carbon Capture and Storage." Energy Policy 38(10): 5653-60. 

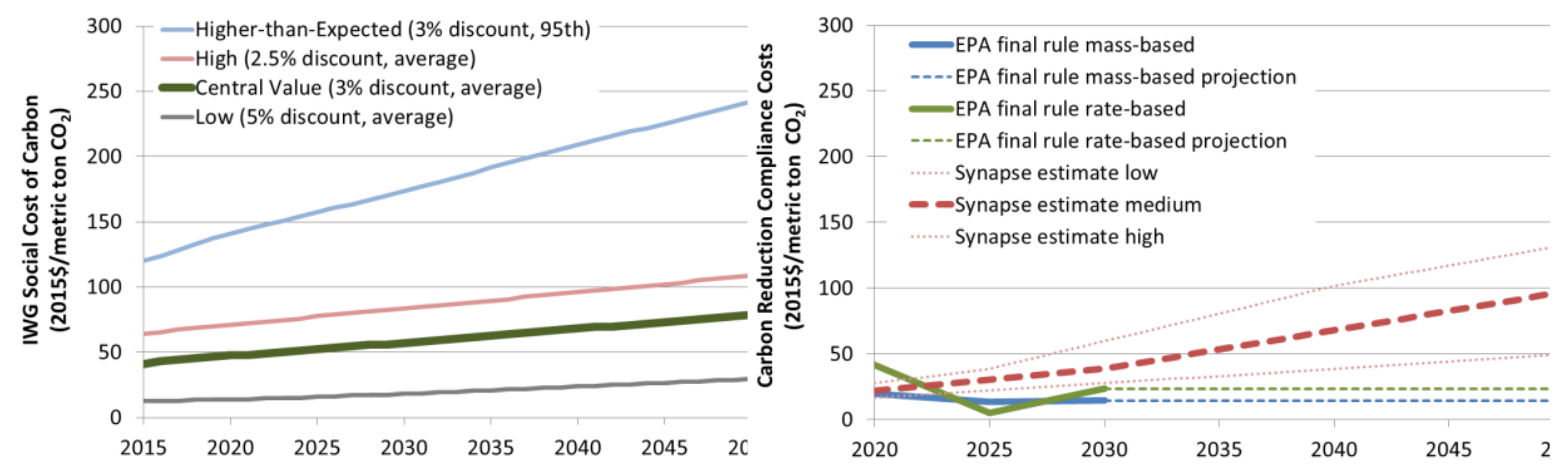

Figure 1: Estimates of the SCC (left) and carbon-reduction compliance costs (right) 

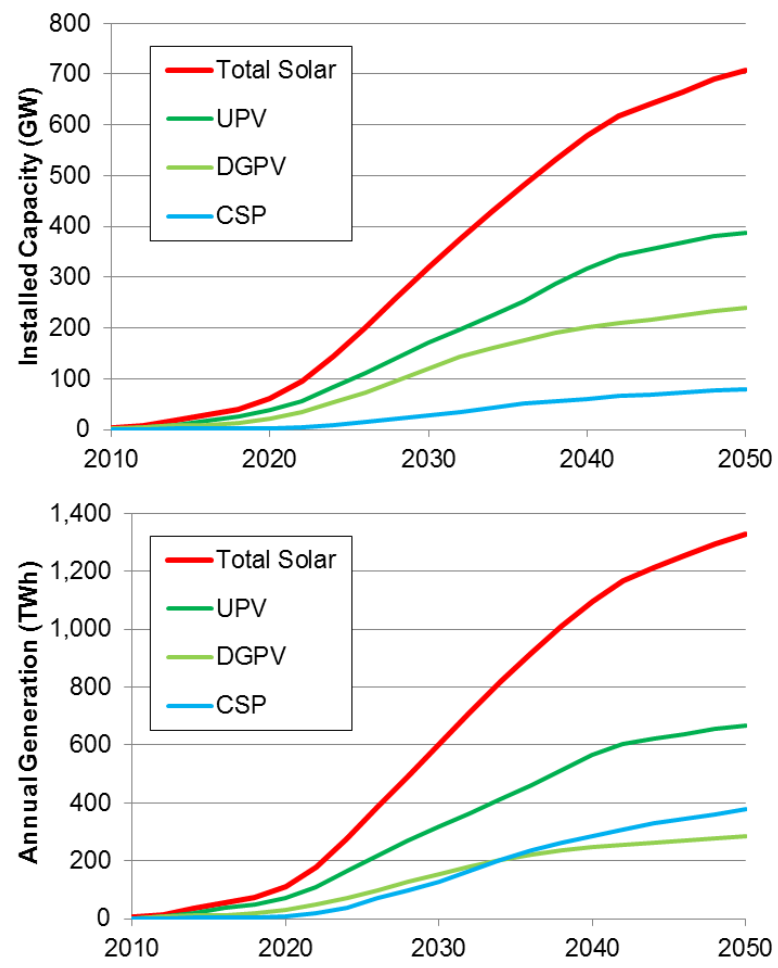

Figure 2. Solar installed capacity (left) and annual generation (right) under the SunShot Vision Scenario 

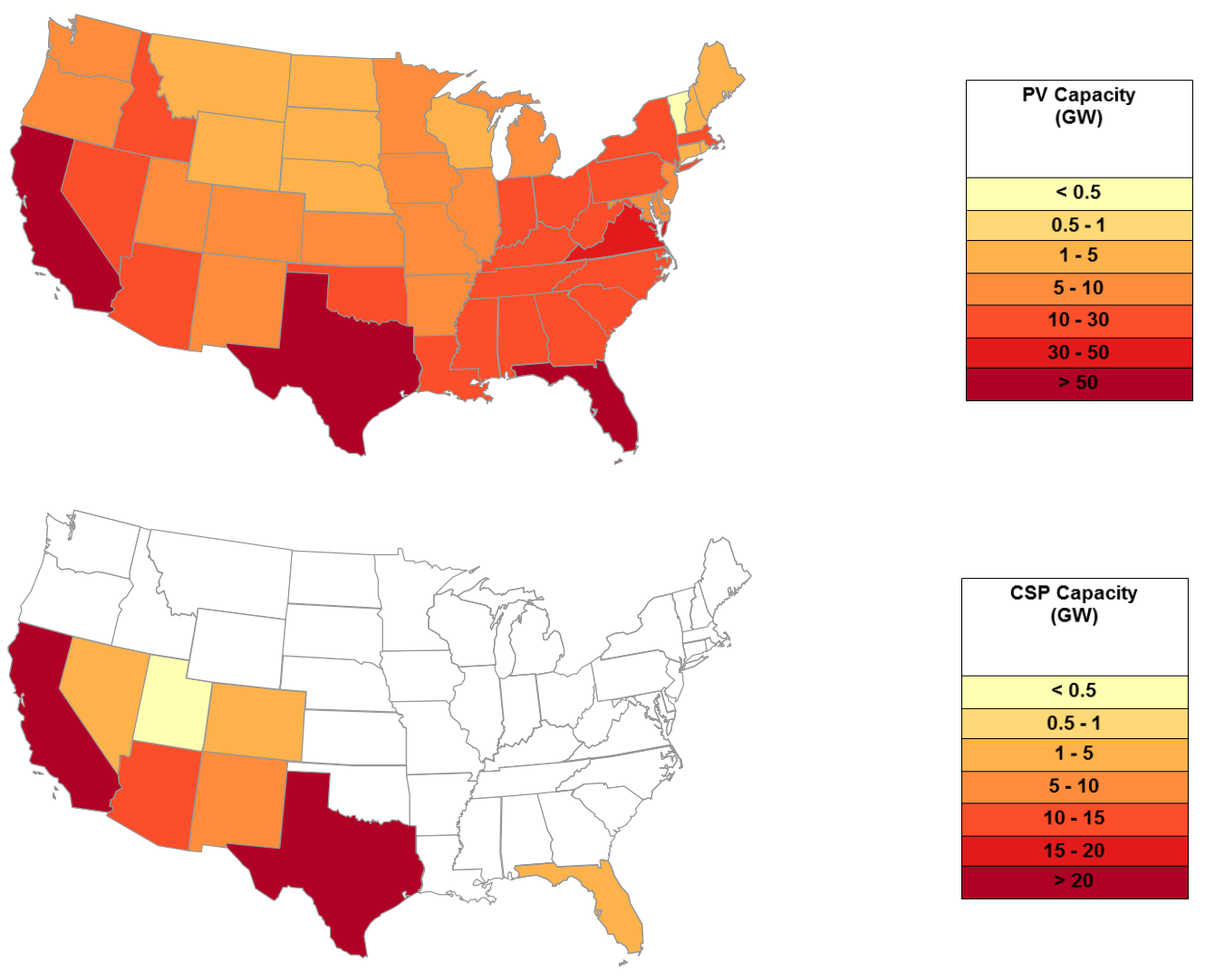

Figure 3. Geographic distribution of 2050 installed PV (top) and CSP (bottom) under the SunShot Vision Scenario 


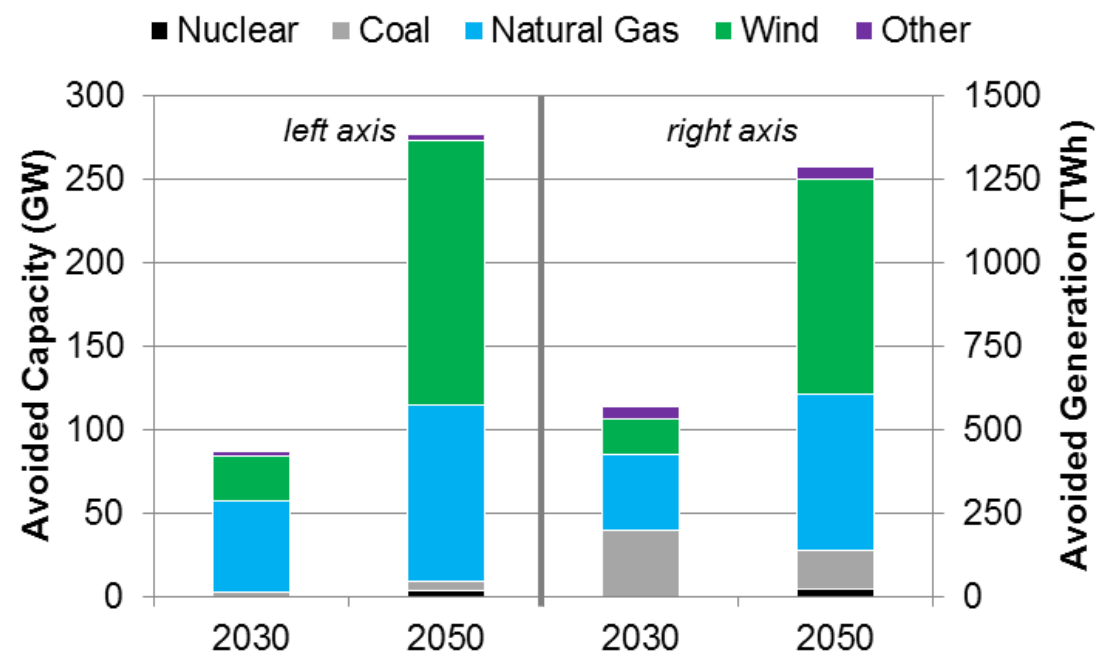

Figure 4. Differences in installed capacity and annual generation between the NNS Baseline and SunShot Vision Scenarios for 2030 and 2050 


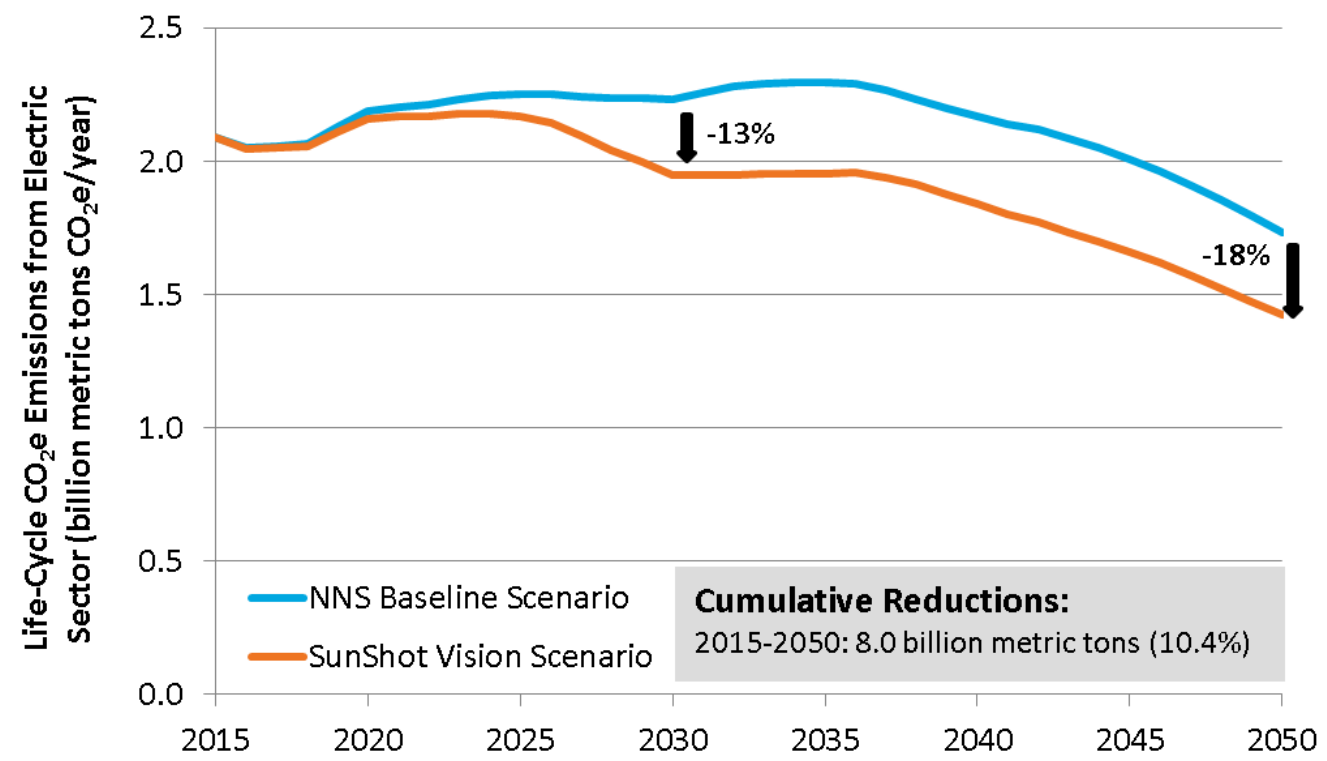

Figure 5. Power-sector life-cycle GHG emissions impacts of SunShot Vision Scenario 

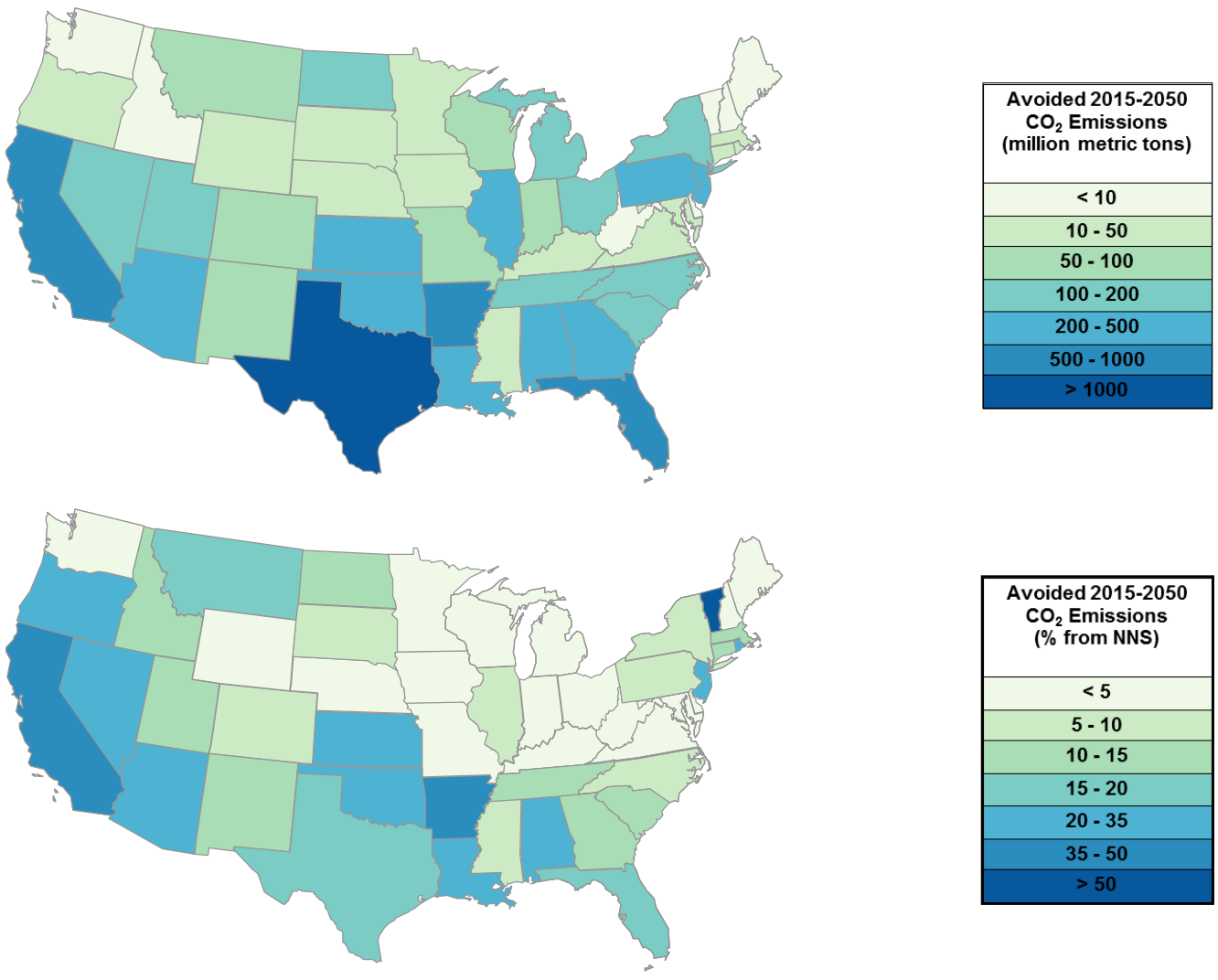

Figure 6. Cumulative 2015-2050 absolute (top) and percent (bottom) combustion-related $\mathrm{CO}_{2}$ reductions of the SunShot Vision Scenario relative to the NNS Baseline Scenario 


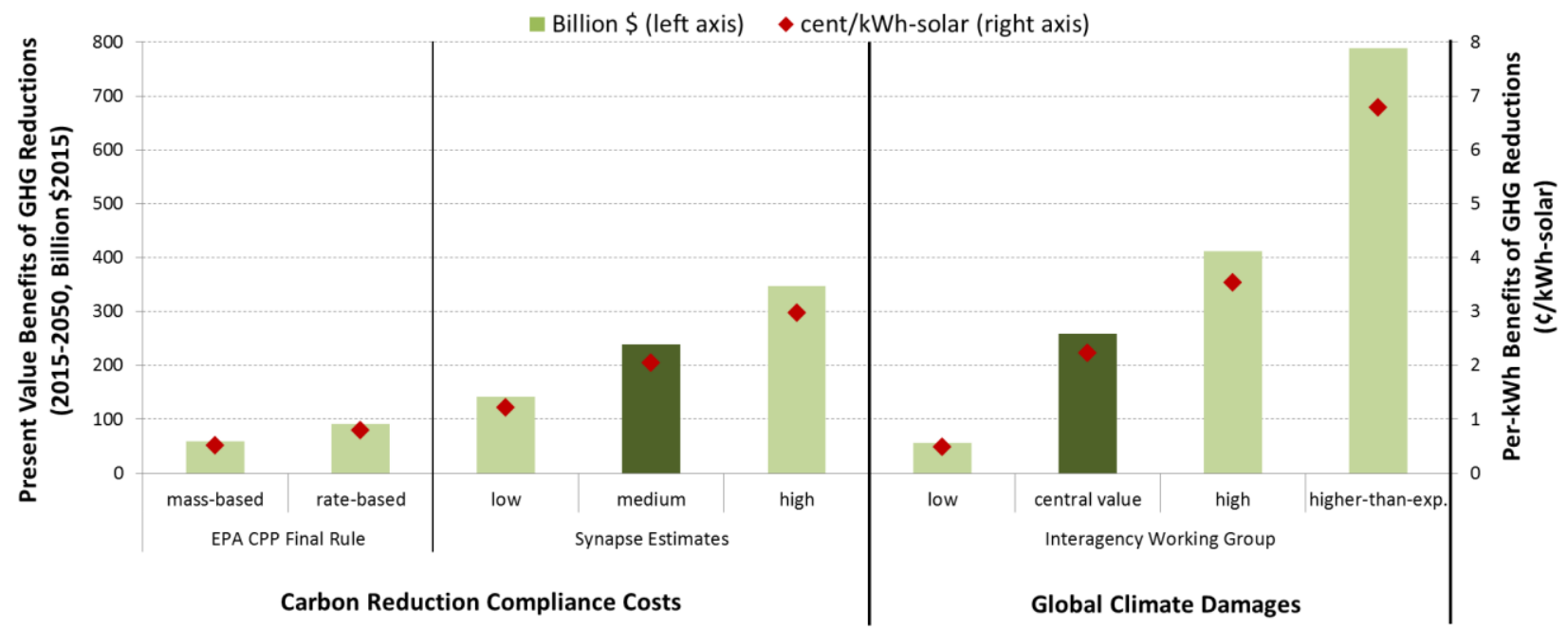

Figure 7. Estimated value of SunShot Vision Scenario GHG-reduction benefits 

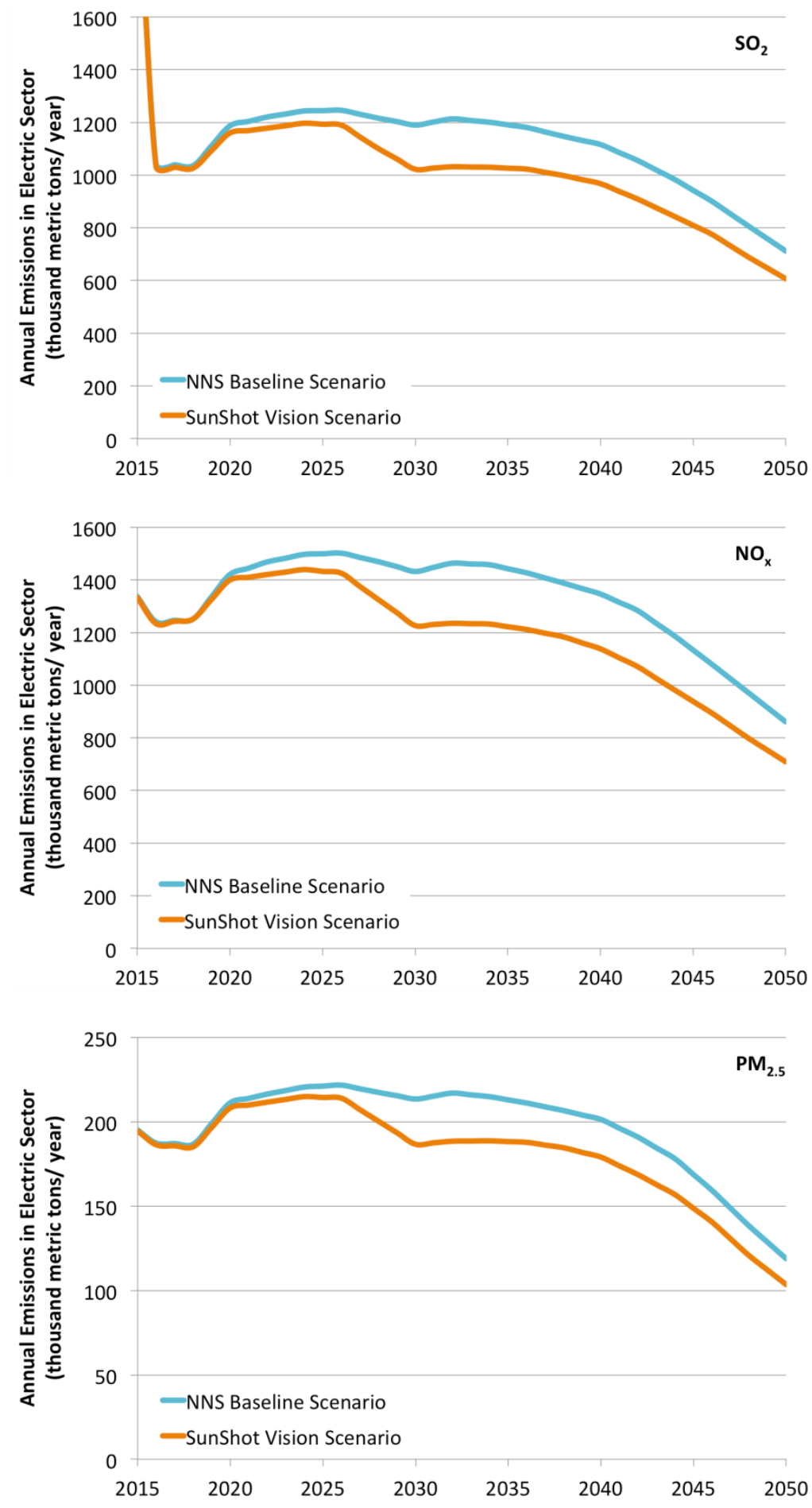

Figure 8. Power-sector $\mathrm{SO}_{2}, \mathrm{NO}_{\mathrm{x}}$, and $\mathrm{PM}_{2.5}$ emissions impacts of SunShot Vision Scenario 
(a) $\mathrm{SO}_{2}$ reductions $(3,800,000$ metric tons total $)$
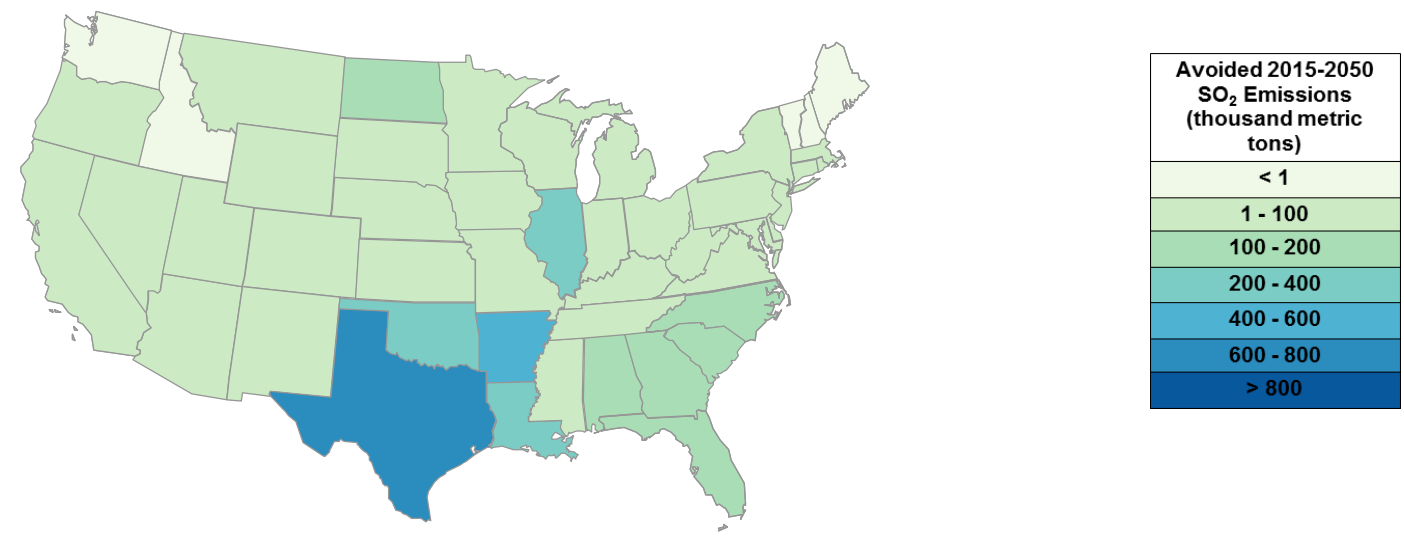

(b) $\mathrm{NO}_{\mathrm{x}}$ reductions $(5,100,000$ metric tons total $)$
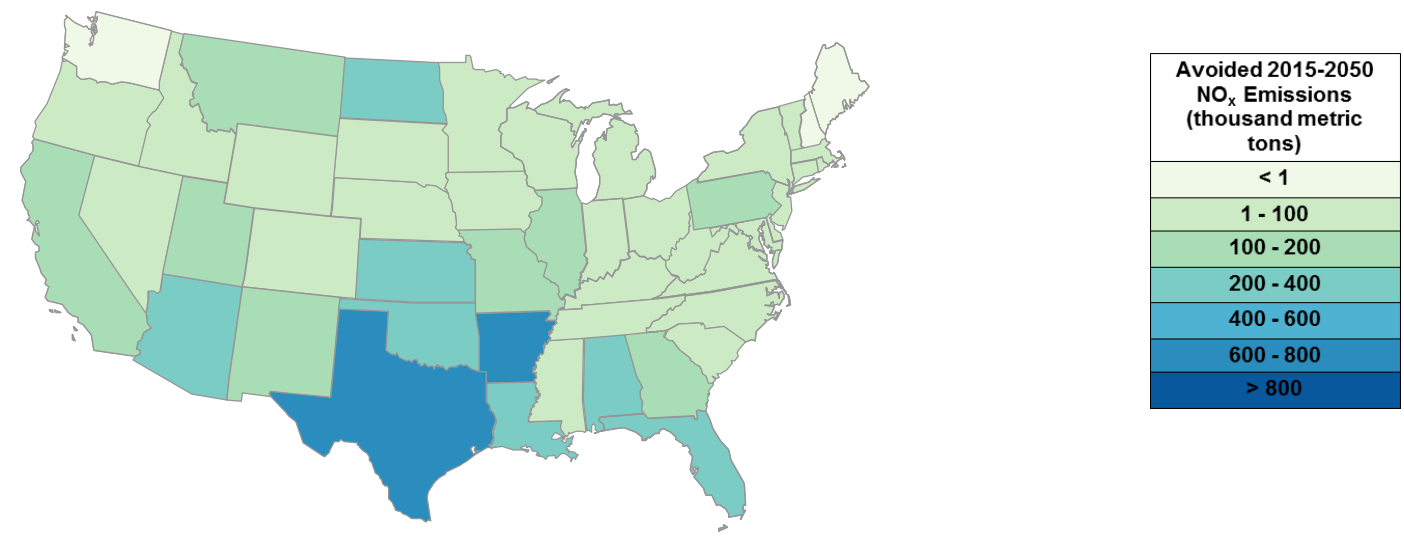

(c) $\mathrm{PM}_{2.5}$ reductions $(600,000$ metric tons total)
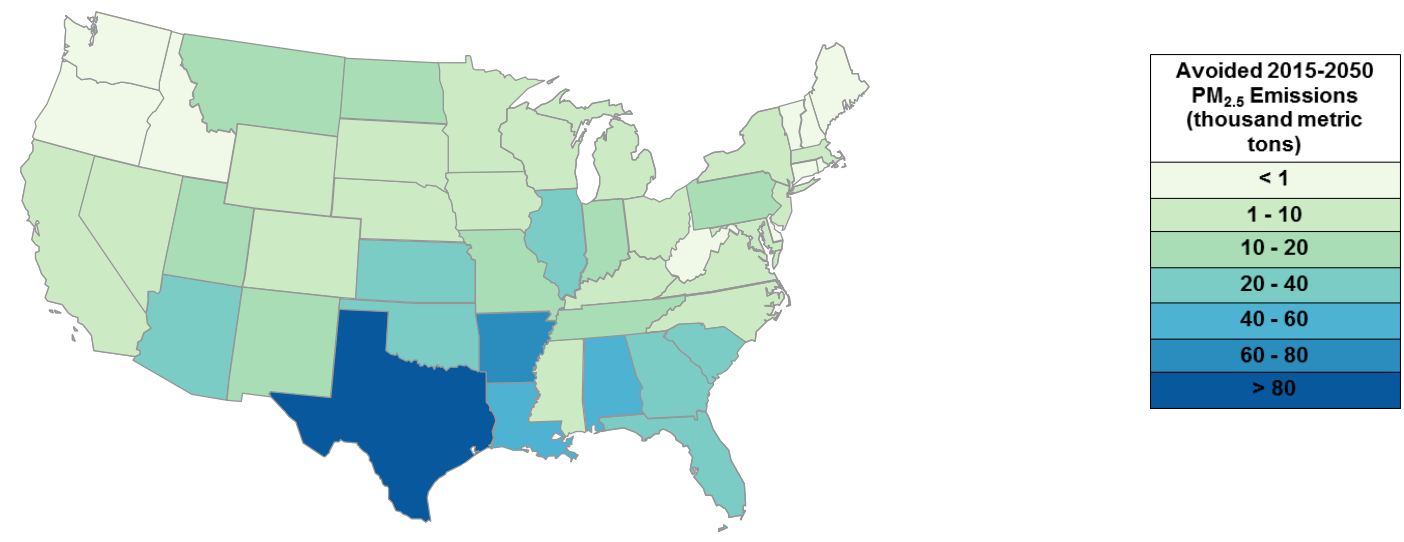

Figure 9. Cumulative 2015-2050 emissions reductions of $\mathrm{SO}_{2}(\mathrm{a}), \mathrm{NO}_{\mathrm{x}}(\mathrm{b})$, and $\mathrm{PM}_{2.5}$ (c) in the SunShot Vision Scenario relative to the NNS Baseline Scenario (All units in thousands of metric tons; note smaller scale for $\mathrm{PM}_{2.5}$ ). 


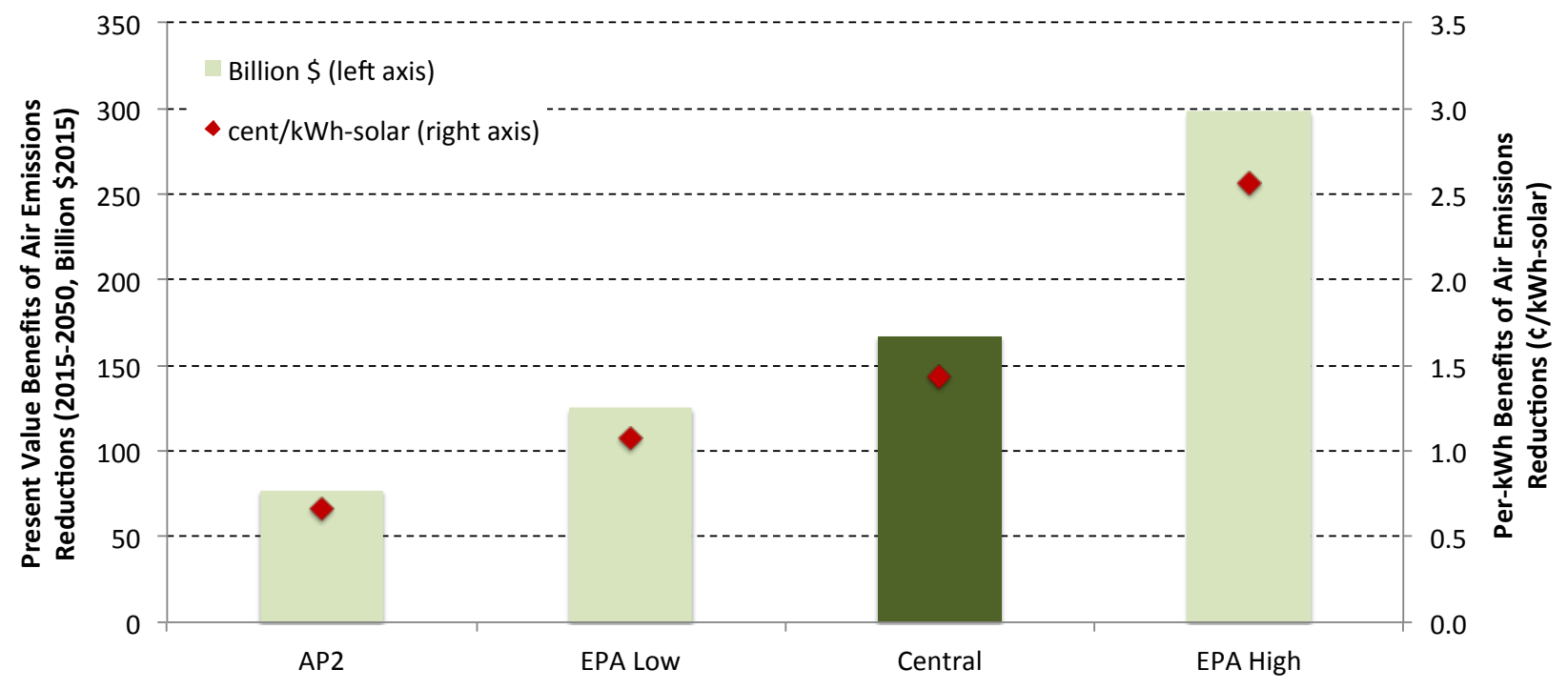

Figure 10. Estimated value of SunShot Vision Scenario $\mathrm{SO}_{2}, \mathrm{NO}_{\mathbf{x}}$, and $\mathrm{PM}_{2.5}$ benefits 
Table 1. Emissions Reductions, Monetized Benefits, and Mortality and Morbidity Benefits over 2015-2050 for the SunShot Vision Scenario Relative to the NNS Baseline Scenario

\begin{tabular}{|c|c|c|c|c|}
\hline Impacts & $\mathrm{SO}_{2}$ & NO $_{\mathbf{x}}$ & $\mathbf{P M}_{2.5}$ & Total \\
\hline \multicolumn{5}{|l|}{ Emissions Reductions: 2015-2050 } \\
\hline $\begin{array}{l}\text { SunShot Vision scenario air-pollution reductions } \\
\text { (millions metric tons) }\end{array}$ & 3.8 & 5.1 & 0.6 & --- \\
\hline \multicolumn{5}{|l|}{ Total Monetized Benefits (Present Value, 2015-2050) } \\
\hline EPA Low benefits (billions 2015\$) & 92 & 21 & 13 & 125 \\
\hline EPA High benefits (billions 2015\$) & 202 & 67 & 28 & 298 \\
\hline AP2 benefits (billions $2015 \$$ ) & 47 & 20 & 10 & 77 \\
\hline \multicolumn{5}{|l|}{ EPA Total Mortality Reductions: 2015-2050 } \\
\hline EPA Low mortality reductions (count) & 18,000 & 4,000 & 3,000 & 25,000 \\
\hline EPA High mortality reductions (count) & 41,000 & 12,000 & 6,000 & 59,000 \\
\hline \multicolumn{5}{|c|}{ 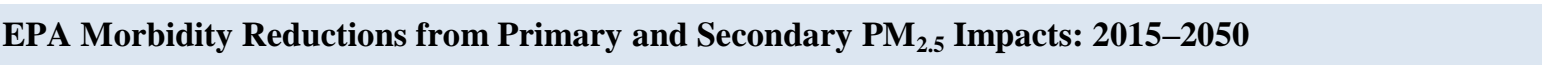 } \\
\hline Emergency department visits for asthma (all ages) & 4,200 & 600 & 800 & 5,600 \\
\hline Acute bronchitis (age 8-12) & 24,400 & 3,400 & 3,500 & 31,300 \\
\hline Lower respiratory symptoms (age 7-14) & 312,800 & 42,200 & 44,400 & 399,400 \\
\hline Upper respiratory symptoms (asthmatics age 9-11) & 486,700 & 61,200 & 63,800 & 611,700 \\
\hline Minor restricted-activity days (age 18-65) & $11,995,300$ & $1,593,800$ & $1,657,700$ & $15,246,800$ \\
\hline Lost work days (age 18-65) & $1,959,600$ & 257,300 & 272,000 & $2,488,900$ \\
\hline Asthma exacerbation (age 6-18) & $1,083,800$ & 153,400 & 151,800 & $1,389,000$ \\
\hline Hospital admissions-respiratory (all ages) & 5,600 & 700 & 800 & 7,100 \\
\hline Hospital admissions-cardiovascular (age > 18) & 7,300 & 900 & 1,000 & 9,200 \\
\hline Non-fatal heart attacks (Peters et al. 2001) & 21,600 & 2,800 & 3,100 & 27,500 \\
\hline $\begin{array}{l}\text { Non-fatal heart attacks (Pooled estimates, } 4 \\
\text { studies) }\end{array}$ & 2,400 & 300 & 300 & 3,000 \\
\hline \multicolumn{5}{|c|}{ EPA Morbidity Reductions from $\mathrm{NO}_{\mathrm{x}}-->$ Ozone Impacts: 2015-2050 } \\
\hline Hospital admissions, respiratory (ages > 65) & --- & 10,500 & --- & 10,500 \\
\hline Hospital admissions, respiratory (ages < 2) & --- & 4,000 & --- & 4,000 \\
\hline Emergency room visits, respiratory (all ages) & --- & 4,400 & --- & 4,400 \\
\hline Acute respiratory symptoms (ages 18-65) & --- & $7,673,600$ & --- & $7,673,600$ \\
\hline School loss days & --- & $2,459,100$ & --- & $2,459,100$ \\
\hline
\end{tabular}

Monetized benefits are discounted at 3\% (real), but emissions reductions and mortality and morbidity values are simply summed over the 2015-2050 period. EPA benefits derive from mortality and morbidity estimates based on population exposure to direct emissions of $\mathrm{PM}_{2.5}$ and secondary $\mathrm{PM}_{2.5}$ (from $\mathrm{SO}_{2}$ and $\mathrm{NO}_{\mathrm{X}}$ emissions) as well as ozone exposure from $\mathrm{NO}_{\mathrm{X}}$ emissions during the ozone season (May-September). AP2 benefits are derived from mortality and morbidity estimates based on population exposure to direct emissions of $\mathrm{PM}_{2.5}, \mathrm{SO}_{2}$, and $\mathrm{NO}_{\mathrm{X}}$ and secondary $\mathrm{PM}_{2.5}$ (from $\mathrm{SO}_{2}$ and $\mathrm{NO}_{\mathrm{X}}$ emissions) as well as ozone exposure from $\mathrm{NO}_{\mathrm{X}}$ emissions during the ozone season (MaySeptember). AP2 benefits also include consequences from decreased timber and agriculture yields, reduced visibility, accelerated degradation of materials, and reductions in recreation services. 

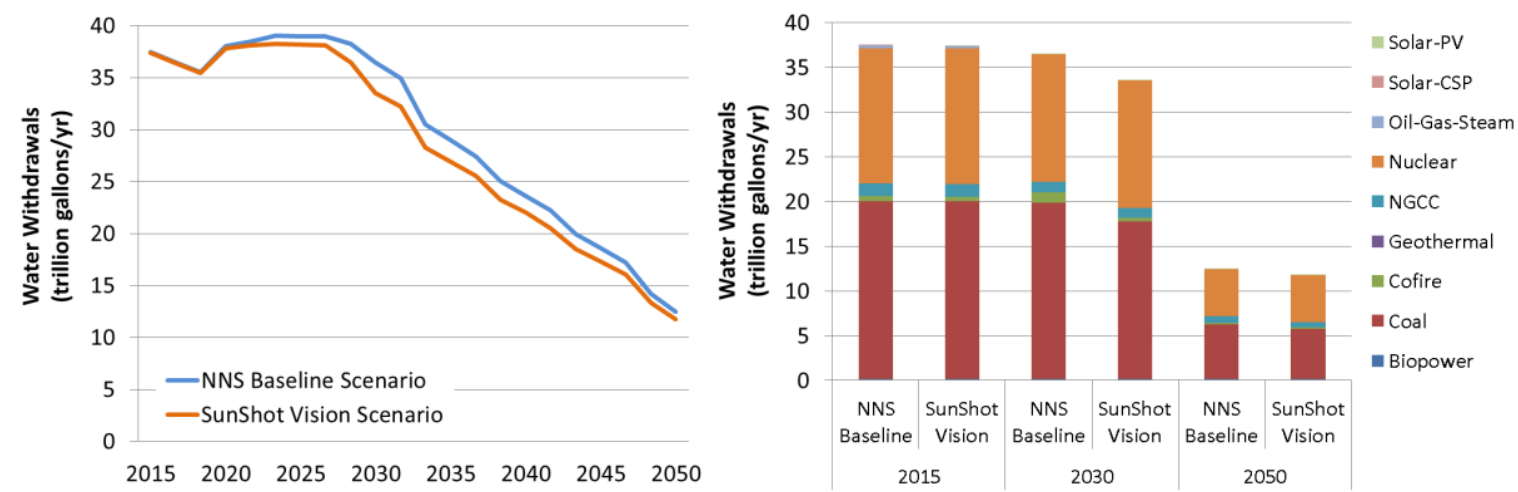

NGCC = natural-gas combined cycle; Cofire: biomass-fossil cofiring

Figure 11. Power-sector water withdrawal impacts of SunShot Vision Scenario from 2015 to 2050 (left) and by Fuel Type in 2015, 2030, and 2050 (right) 

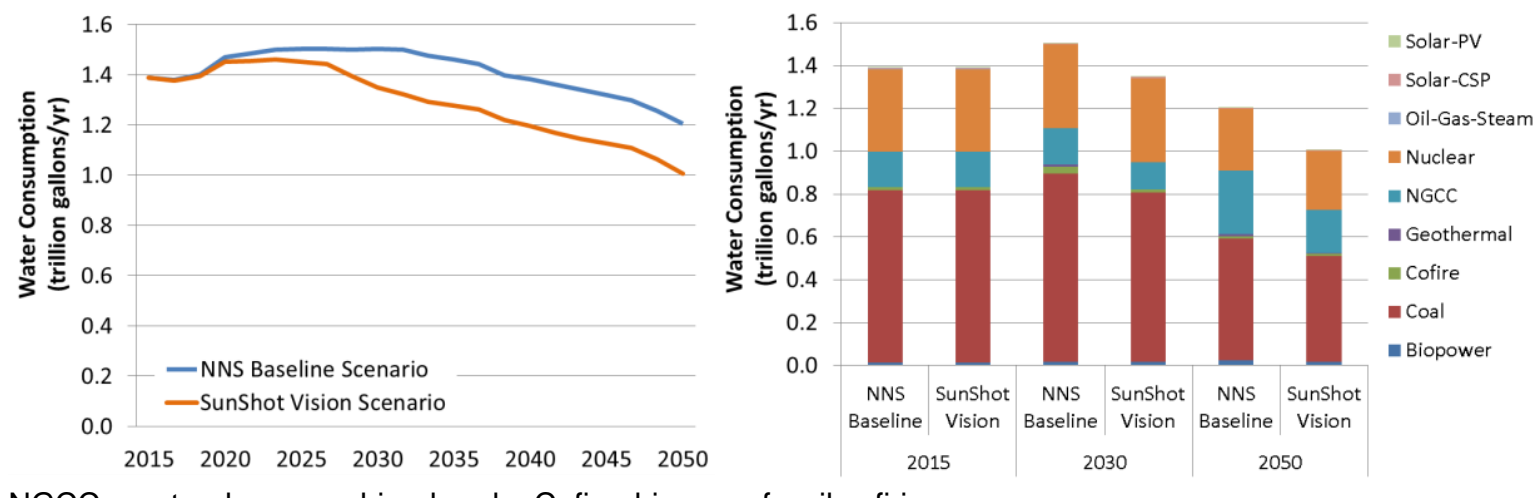

NGCC = natural-gas combined cycle; Cofire: biomass-fossil cofiring

Figure 12. Power-sector water consumption impacts of the SunShot Vision Scenario from 2015 to 2050 (left) and by fuel type in 2015, 2030, and 2050 (right) 
(a) 2050 Avoided Water Withdrawal ( 700 billion gallons)
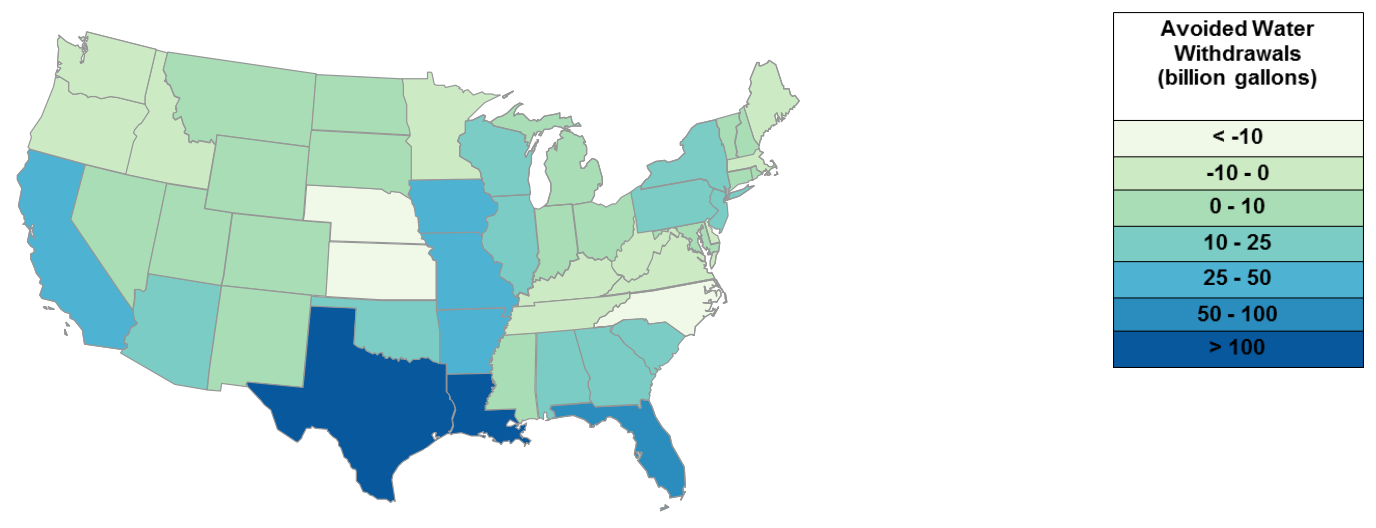

(b) 2050 Avoided Water Consumption ( 200 billion gallons)
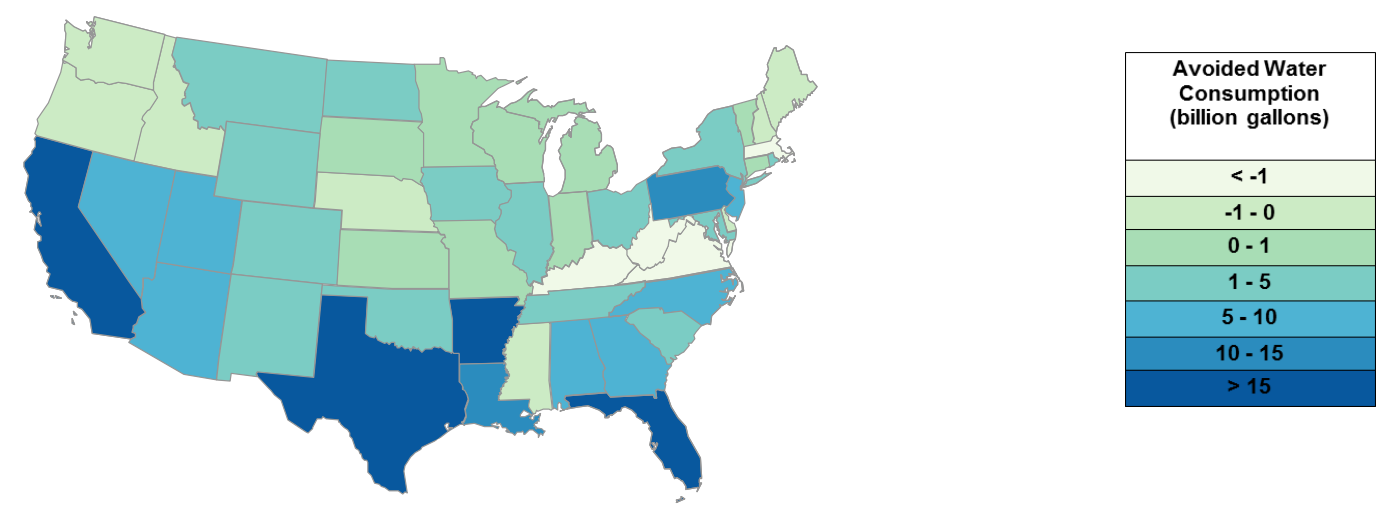

Figure 13. Changes in water withdrawals (top) and water consumption (bottom) in the SunShot Vision Scenario Relative to the NNS Baseline Scenario 


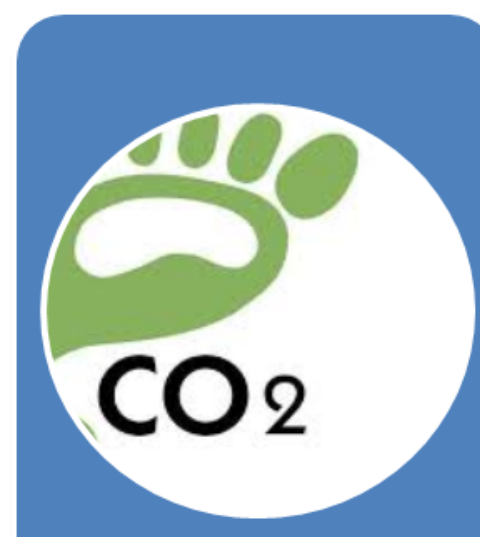

$10 \%$ reduction in powersector life-cycle

greenhouse gas emissions: 2015-2050

\section{$\$ 259$ billion}

in present-value benefits

of avoided global damages range: $\$ 56-\$ 789$ billion

\section{$\$ 238$ billion}

in present-value benefits of compliance cost offsets range: $\$ 60-\$ 347$ billion

Equivalent to: $\sim 2 థ / \mathrm{kWh}$-solar for central estimates

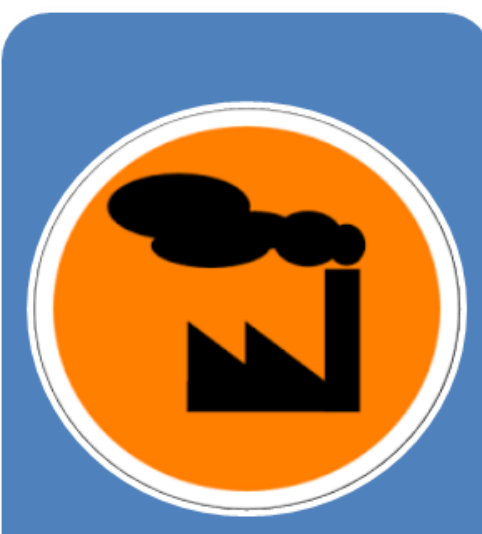

$9 \%\left(\mathrm{SO}_{2}\right), 11 \%\left(\mathrm{NO}_{\mathrm{v}}\right)$, and $8 \%\left(\mathrm{PM}_{2.5}\right)$ reduction in power-sector emissions:

$$
\text { 2015-2050 }
$$

\section{$\$ 167$ billion}

in present-value health and environmental benefits range: $\$ 77-\$ 298$ billion

Equivalent to:

$\sim 1.4 \$ / \mathrm{kWh}$-solar for central estimates

\section{5,000-59,000}

avoided premature mortalities: 2015-2050

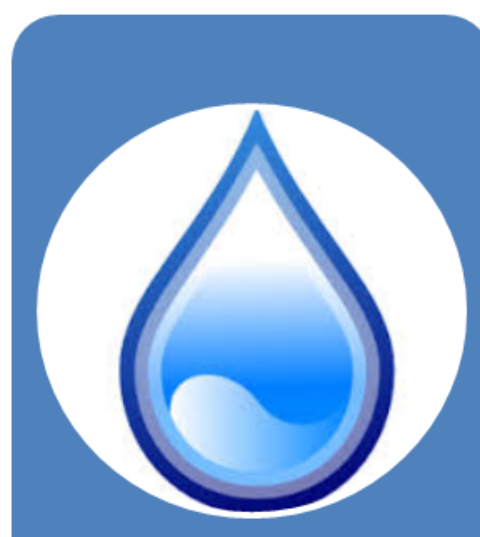

$4 \%$ reduction in powersector water withdrawals and $9 \%$ reduction in water consumption: 2015-2050

Withdrawals fall in 35 states in 2050;

consumption falls in 36 states; notably including many drought-prone and arid states

Consumption savings in $2050=$ water demands of:

1.3 million households

Figure 14. Environmental and health benefits of achieving the SunShot Vision Scenario (14\% of U.S. electricity demand by 2030 and $27 \%$ by 2050) 